\title{
The Impact of Management Incentives on Earnings Management and Audit Committee Communication with the Auditor on the Quality of Auditor's Judgment
}

\author{
Mohammad Reza Nik Bakht * \\ Associate Professor University of Tehran, Faculty of Management \\ (Department Of Accounting), Tehran, Iran, Corresponding Author, Email: \\ mnikbakht@ut.ac.ir \\ Amir Hossein Hossein Pour \\ Ph.D Student Of Accounting, University Of Tehran, Faculty Of \\ Management, Tehran, Iran. \\ amhosseinpour@Yahoo.Com
}

\begin{abstract}
:
Increasing Emphasis On Internal (Charter Of The Audit Committee) And External (Public Company Accounting Oversight Board Standards) Laws And Regulations Regarding The Audit Committee Communication With The Independent Auditor, In Order To Improve The Independent Auditor Performance And The Quality Of Financial Reporting, This Study Examined The Effect Of Management Incentives On Earnings Management And The Audit Committee Communication With The Independent Auditor On The Quality Of Auditor's Judgment. It Should Be Noted That, The Research Method Is Experimental, Which Is Conducted Through A $2 * 2$ BetweenSubjects Experiment, With Experimental Design Post Test With Control Group, Consisting Of The Variables "Management Incentives On Earnings Management" And "Audit Committee Communication With The Independent Auditor". Participants In The Test Are Managers Of Audit Firms And This Research Were Conducted In Year 2019. Statistical Test Method Is Also MANCOVA. The Results Of The Analysis On The Data Extracted From 64 Managers Of Audit Firms, Indicate That "Management Incentives On Earnings Management" And "Audit Committee Communication With The Independent Auditor" Has A Positive And Significant Effect On The Quality Of Auditor's Judgment And Also The Interaction Of "Management Incentives On Earnings Management And Audit Committee Communication With The Independent Auditor" Has A Positive And Significant Effect On The Quality Of Auditor's Judgment. Finally, It Was Concluded From The Results Of The Study That According To Source Credibility Theory, When There Are High Management Incentives On Earnings Management, Audit Committee
\end{abstract}


Semiannually journal of Value \& Behavioral Accounting dof 10.29252/aapc.5.9.189

Communication With The Independent Auditor Has A Positive And Significant Effect On The Quality Of Auditor's Judgment.

Keywords: Management Incentives on Earnings Management, Audit Committee, the Quality of the Auditor's Judgment, Competing Preferences, Information Source Credibility

\section{Copyrights $\mathcal{C O}(1)($}

This license only allowing others to download your works and share them with others as long as they credit you, but they can't change them in any way or use them commercial. 


\section{مقاله يخووهشى}

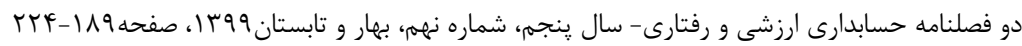

\section{تاثير " انغيزه هاى مديريت نسبت به مديريت سود" و "ارتباط كميته حسابر سى با حسابرس مستقل " بر كيفيت قضاوت حسابرس

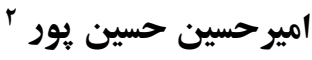

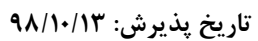

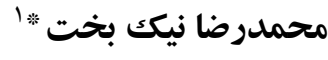

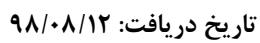

جكکبه

با افزايش تاكيد از طرف قوانين و مقررات داخلى (منشور كميته حسابرسى) و خارجى

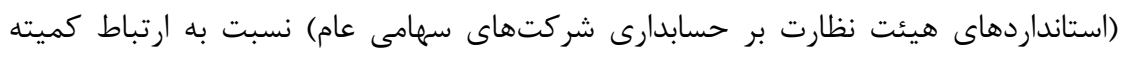

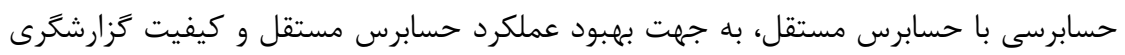

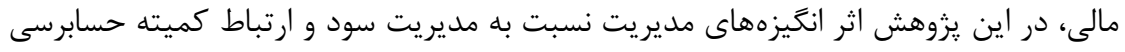

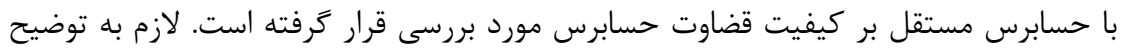

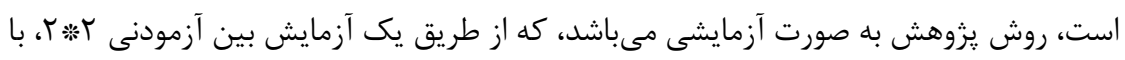

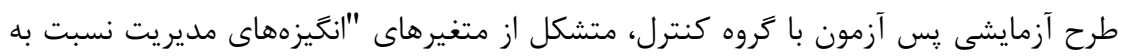

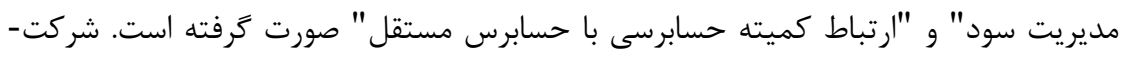

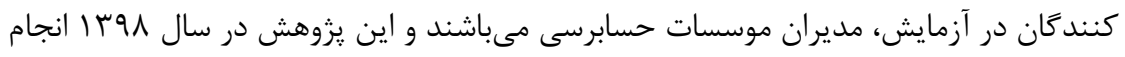

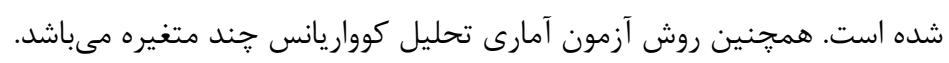

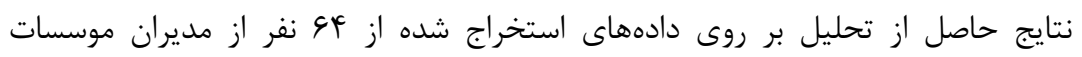

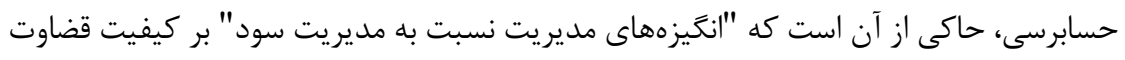

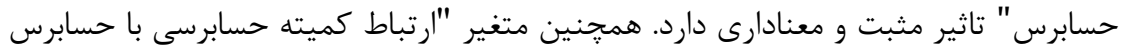

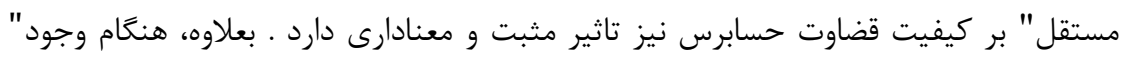

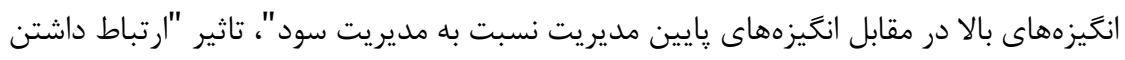

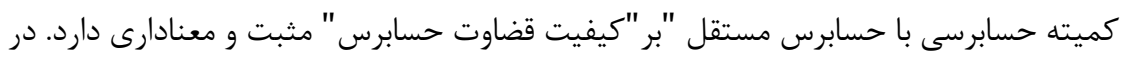

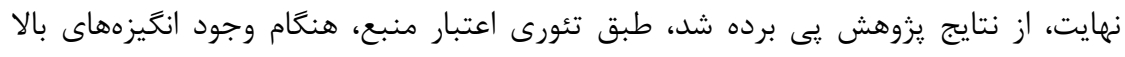

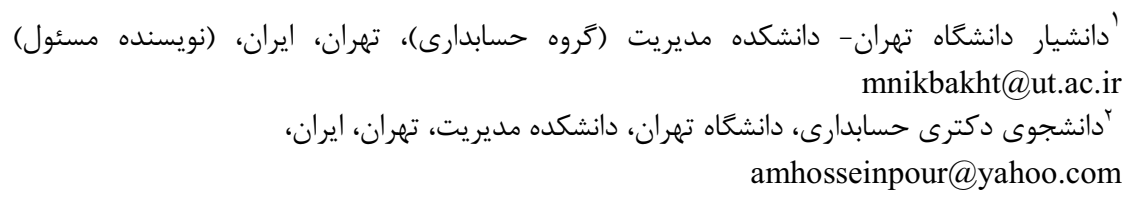




$$
\text { حسابريت نسبت به مديريت سود، ارتباط كميته حسابرسى با حسابرس مستقل بر كيفيت قضاوت }
$$


راهبرى شركتى، تصوير سازمان را بهبود مىبخشد و در زمينه حركت به سمت بهبود عملكرد

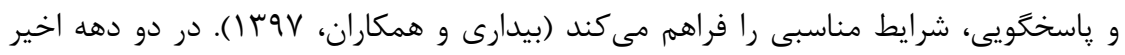
راهبرى شركتى تغييرات زيادى داشته است كه از جمله مىتوان به نقش كميته حسابرسى اشاره

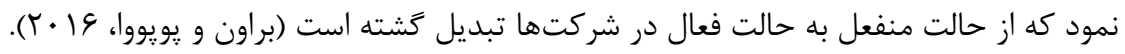
در سالهاى اخير، كشورهاى توسعه يافته شاهد ظهور و تكامل شتابان كميته حسابرسى بوده است. كميتههاى حسابرسى يك بخش ارزشمند و مكمل از فعاليتهاى راهبرى در سازمانها

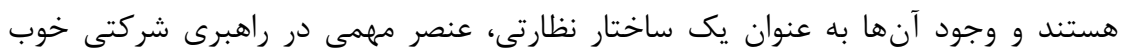

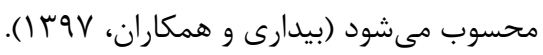
طبق يزوهشهاى پيشين، كميته حسابرسى مى تواند مديريت سود فرصت طلبانه را از طريق ارزيابى شايستخى و استقلال حسابرسان مستقل و تشكيل جلسه و صحبت با مديريت شركت و و حسابرسان مستقل، در رابطه با مباحث مهرم و كليدى گزارشخرى مالى، كاهش دهابى دهد (هردمن،

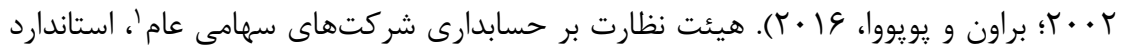
شماره 19 با عنوان "ارتباط با كميتههاى حسابرسى" رأ بانه جهت افزايش ارتباط بين حسابرس

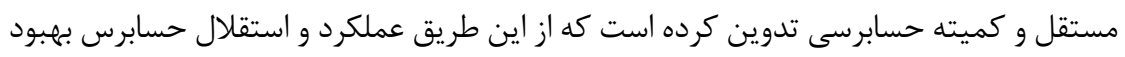

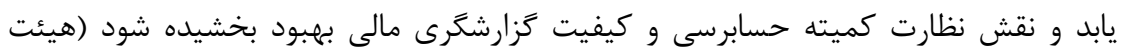

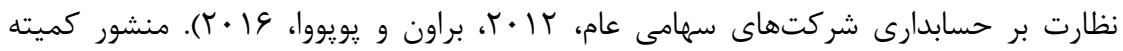

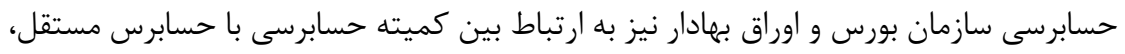

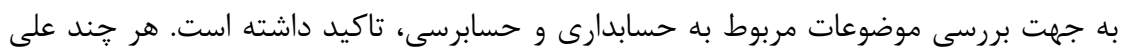
رغم قوانين و مقررات مذكور، حسابرسان به نقش مديريت در راهبرى شركتى توجه زيادى دارند

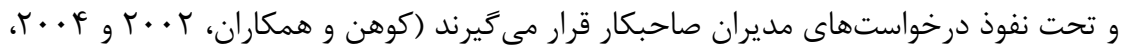

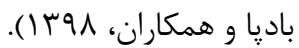

در يزوهشهاى كذشته نياز به بررسى ارتباط بين اركان راهبرى شركتى، به جهت دستيابى

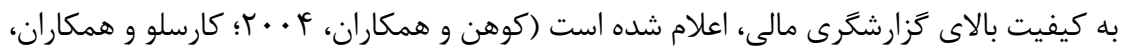

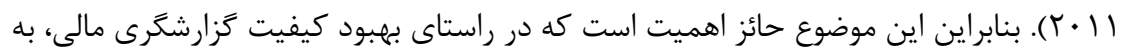
بررسى اين موضوع يرداخته شود كه جطور مكانيزم تاثير يك ركن مشخصى از راهبرى شركتى (به طور مثال ارتباط كميته حسابرسى با حسابرس مستقل) مى تواند تحت تاثير اركان ديخر قرار

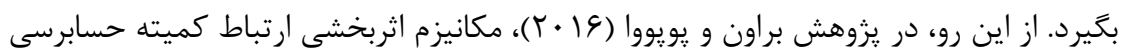

1. Public Company Accounting Oversight Board (PCAOB) 
با حسابرس مستقل، با توجه به قرابت بين حسابرس و مديريت صاحبكار، با توجه به قوانين و

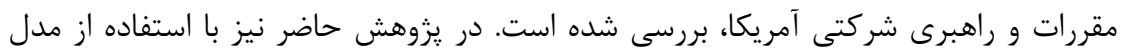

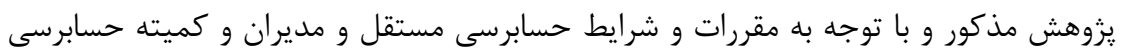
شركتهاى بورسى ايران، اينكه از طرفى سازمان بورس و اوراق بهادار الزام به ارتباط كميته

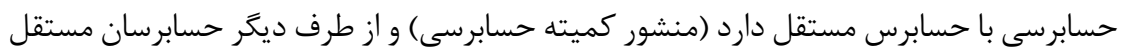

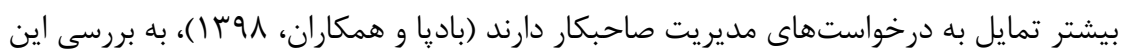

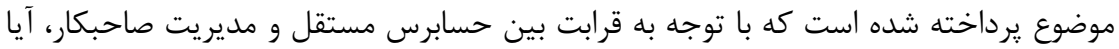
ارتباط كميته حسابرسى با حسابرس مستقل، بر كيفيت قضاوت حسابرس مستقل، تاثير مى كذارن؟

اهميت يزوهش حاضر در تجزيه و تحليل تفكرات موجود بيرامون نحوه تركيب دو عنصر

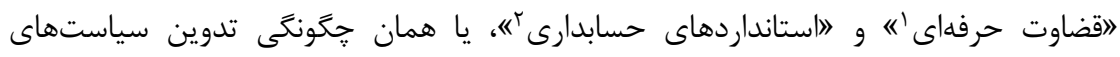

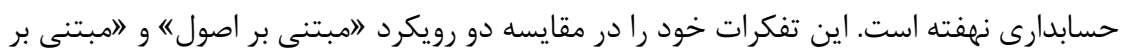

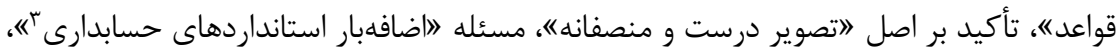

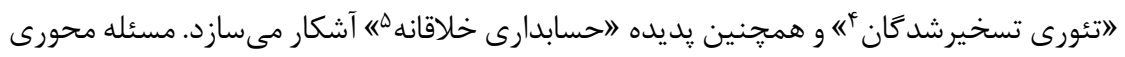

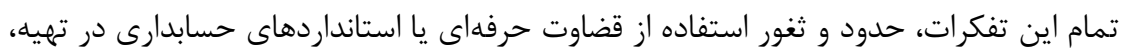

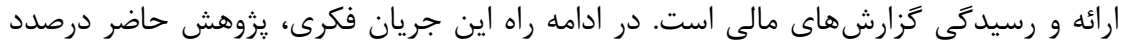

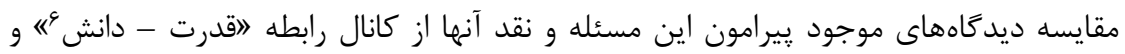

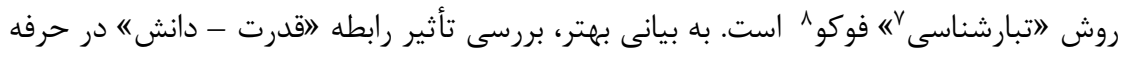

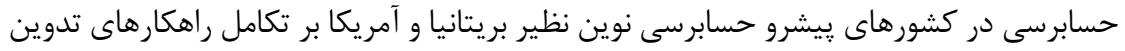

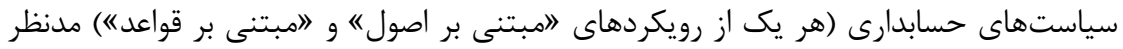

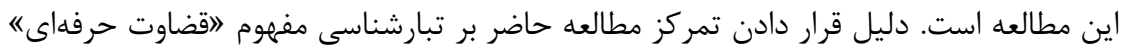
در كشورهاى غربى، ريشه داشتن حسابرسى نوين در كشورهايى نظير بريتانيا و آمريكاست.

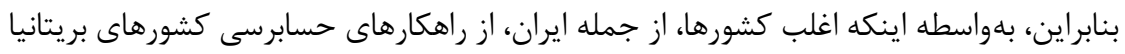

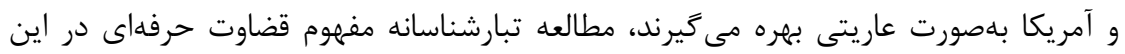

${ }^{1}$ Professional Judgment

${ }^{2}$ Accounting Standards

${ }^{3}$ Accounting Standards Overload

4 Capture Theory

${ }^{5}$ Creative Accounting

${ }^{6}$ Power-Knowledge

${ }^{7}$ Genealogy

${ }^{8}$ Foucault 
كشورها، يافتههايى بنيادينتر و حقيقى تر از مطالعه اين مفهوم در ايران بدست مى دهد. باور بر

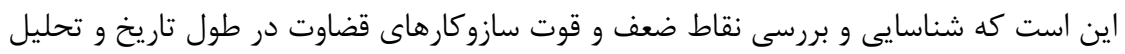

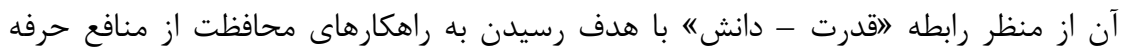

حسابرسى، يافته هايى بكر فراهم مئسازد.

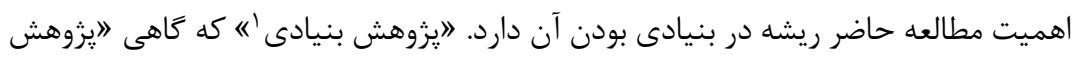

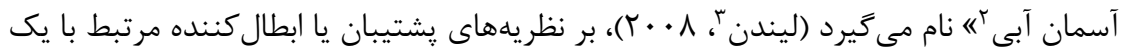

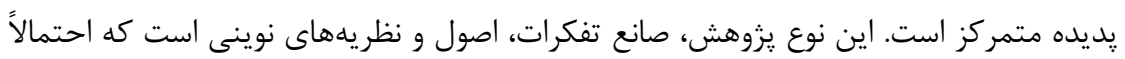

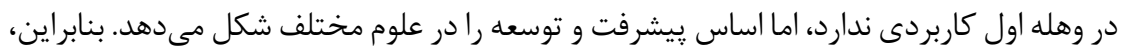

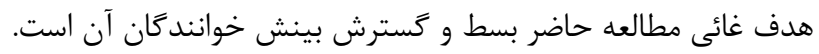

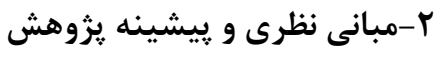

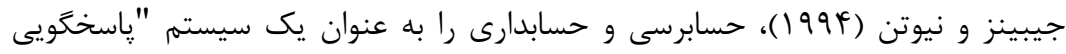

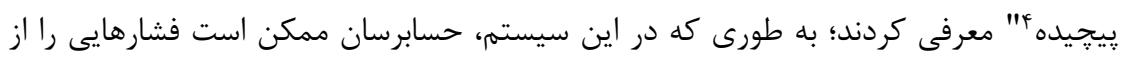

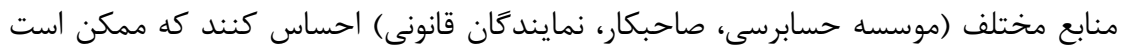

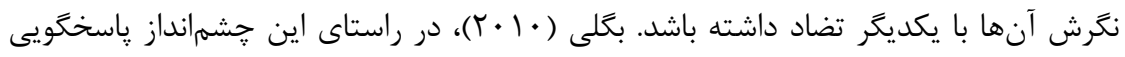

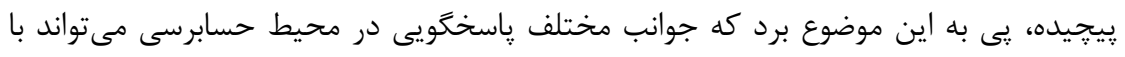

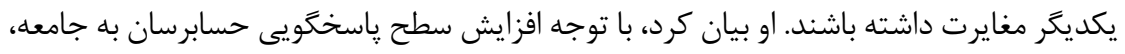

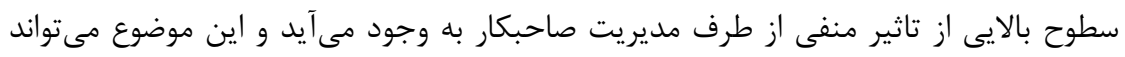

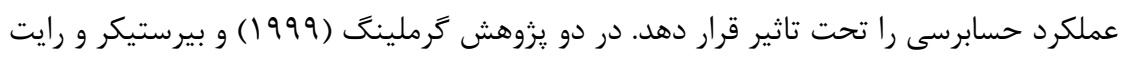

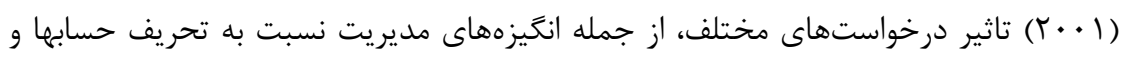

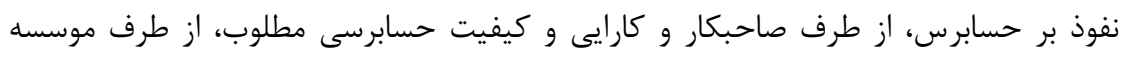

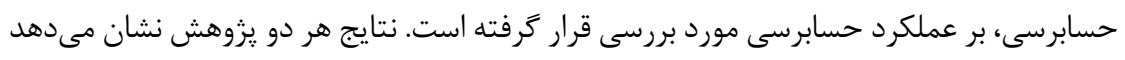

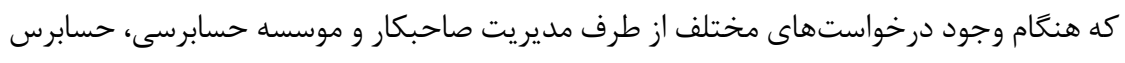
به طرف درخواست مديريت صاحبكار تمايل دارد.

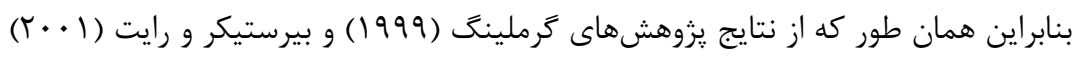

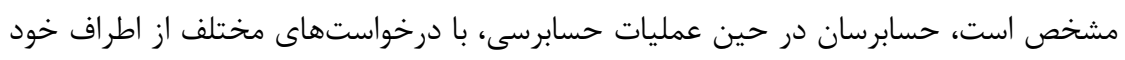

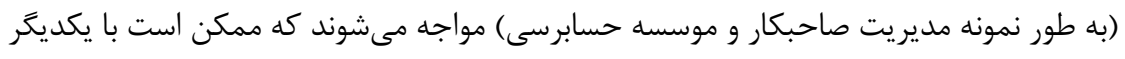

${ }^{1}$ Basic Research

${ }^{2}$ Blue Sky Research

${ }^{3}$ Linden

${ }^{4}$ Complex Accountability 
در تضاد باشند، كه در اصطلاح به آنها ترجيحات رقابتى در عملكرد حسابرسى ' گفته مىشود

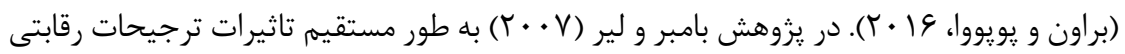

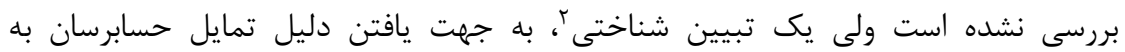
درخواستهاى مديريت صاحبكار در مقابل درخواستهاى بيان شده از طرف روساى خود، ارائه

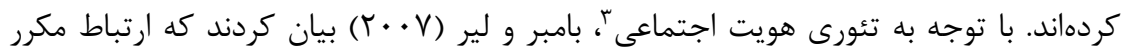

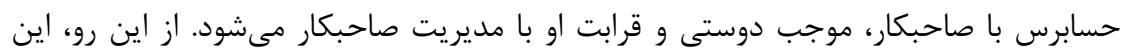
قرابت و دوستى، منجر به اين مىشود كه حسابرسان تسليم درخواستهاى صاحبكار شوند و به نوعى مديريت بر كيفيت قضاوت حسابرس نفوذ داشته باشد. تئورى هويت اجتماعى، تصميمات

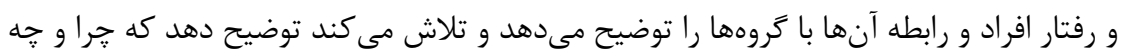
وقت افراد خود را به عنوان عضوى از يك گروه خاص تلقى مى كنند. براساس اين تئورى، هويت

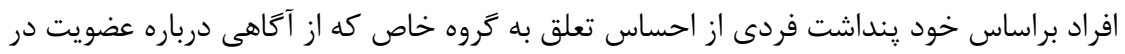

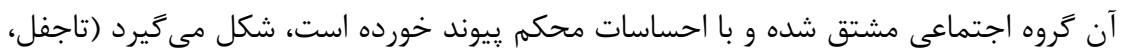

.(19VF

طبق تئورى اعتبار منبعُ'، توانايى منبع اطلاعاتى جهت نفوذ بر شخص مقابل، بستكى به

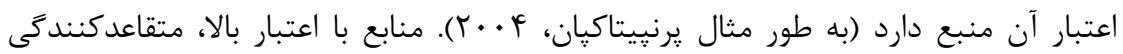

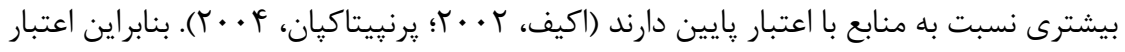
منبع، جهت رسيدن به هدف، مهرم است. تئورى اعتبار منبع بيان ميى كنند كه اعتبار منبع وابسته

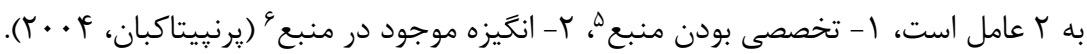
تخصصى بودن منبع (شايستكى و صلاحيت)، به توانايى منبع جهت بيان درست حقايق اطلاق

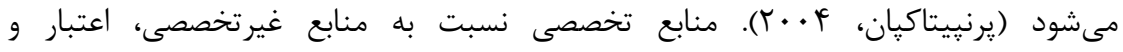

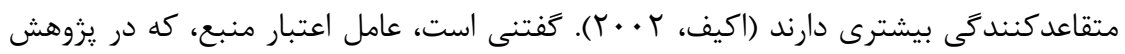
حاضر استفاده شده است، انگيزه موجود در منبع مىباشد. طبق يزوهشهاى مرتبط با تئورى اعتبار منبع، انگيزه موجود در منبع، عبارتست از ترغيب منبع جهت تحريف منبع اطلاعاتى و

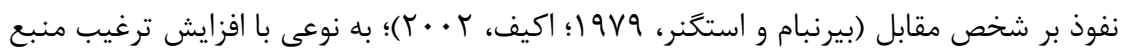

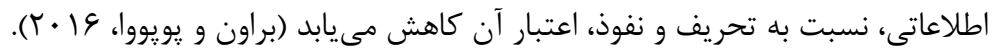

1 Competing Preferences for Auditor Performance

${ }^{2}$ Cognitive-Based

3 Social Identity Theory

4 Source Credibility Theory

${ }^{5}$ Source Expertise

${ }^{6}$ Source Incentive 
مديران صاحبكار اغلب از انكَيزهاى شخصى يا شركتى جهت تحريف صورتهاى مالى استفاده

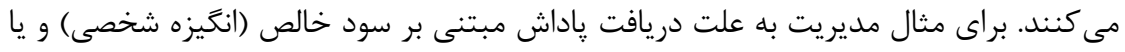

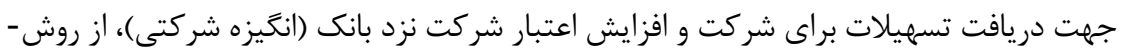

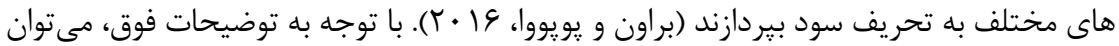

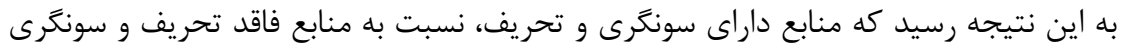

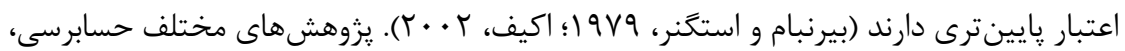
شواهدى مرتبط با تئورى اعتبار منبع ارائه كردهاند و به اين نتيجه رسيدهاند كه هر جها خه حسابرسان

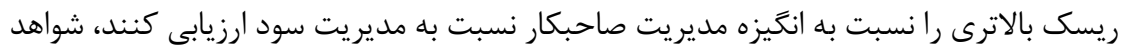

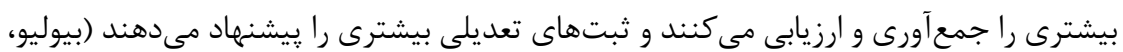

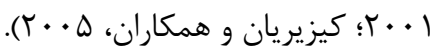

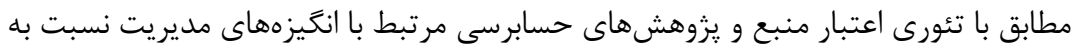

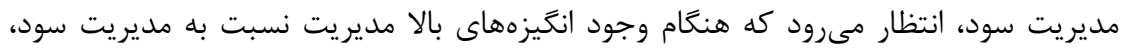

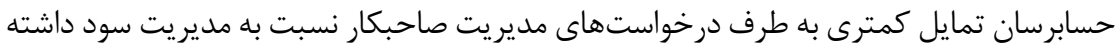

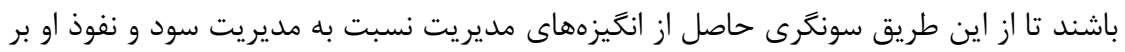

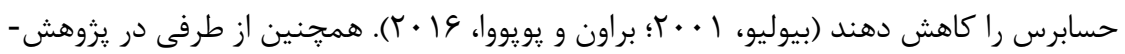
هاى مختلف به اين نتيجه رسيده شده است كه كميتههاى حسابرسى حمايت زيادى از كيفيت

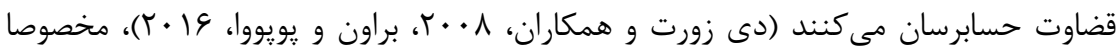

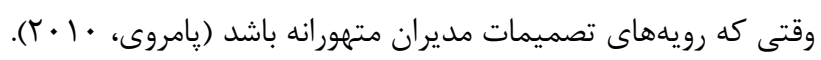

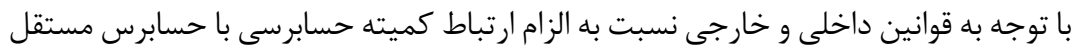

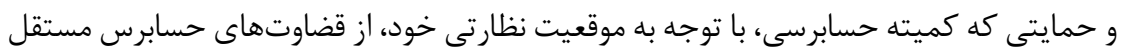

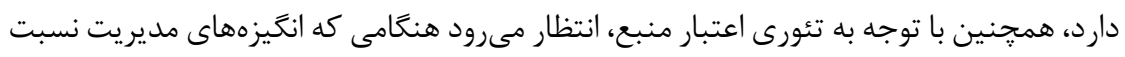

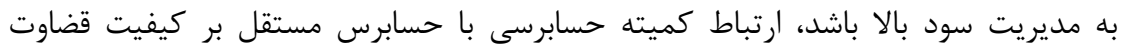
حسابرس تاثير زيادى داشته باشد.

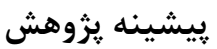

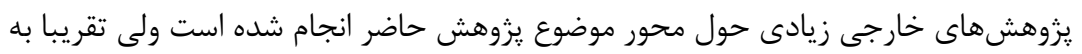

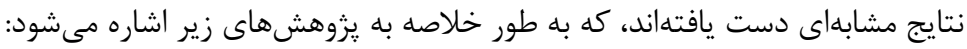

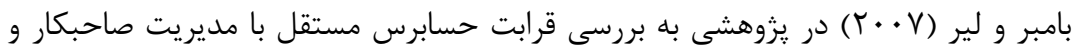

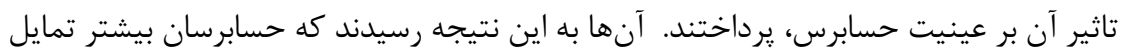

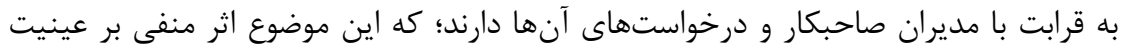




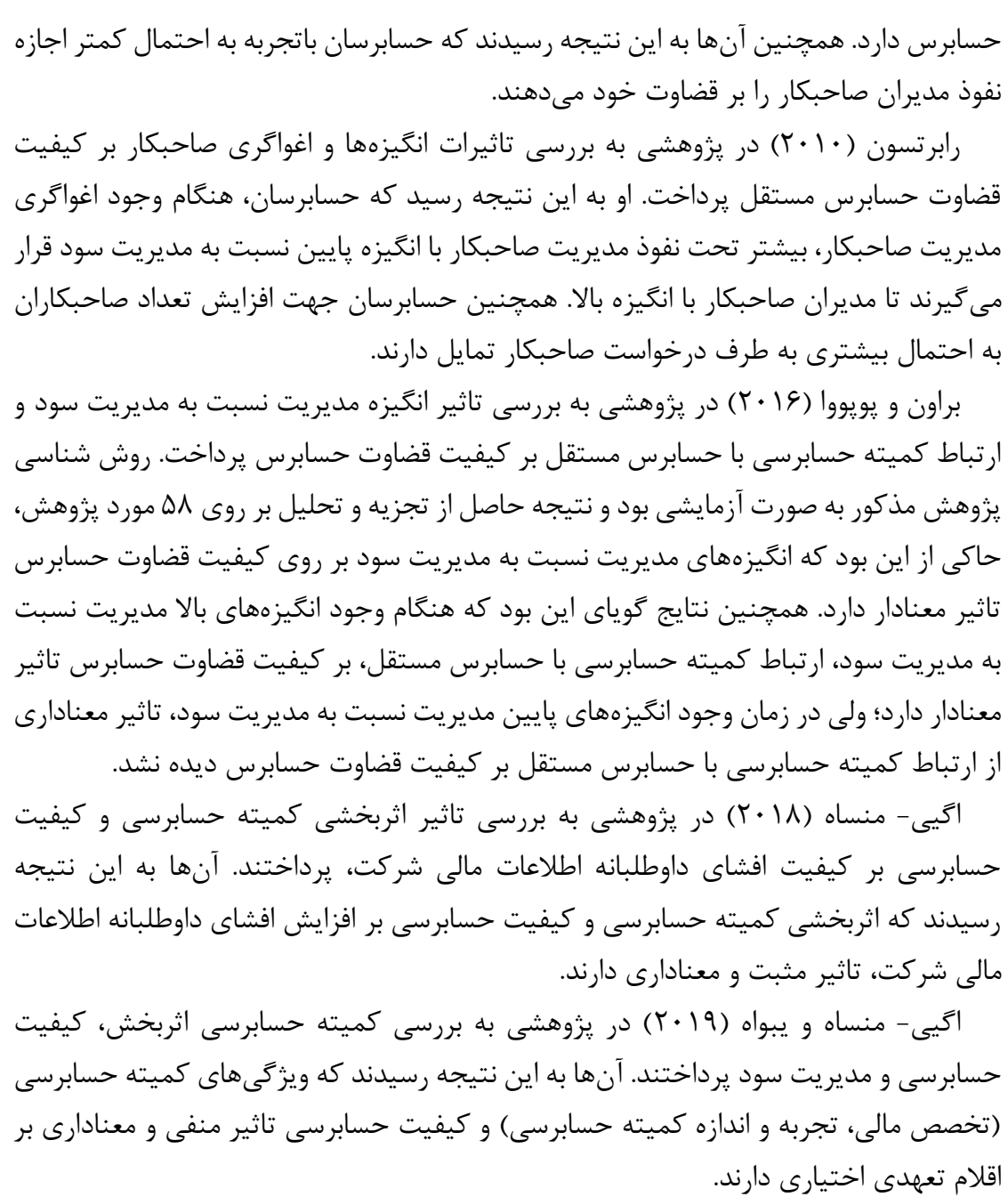

يزوهشهاى داخلى زيادى نيز حول محور موضوع يزوهش حاند حاضر انجام شده است، كه به طور

خلاصه به يزوهشهاى زير اشاره مىشود:

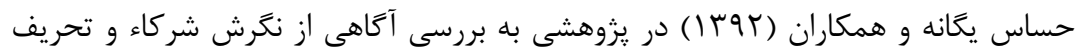

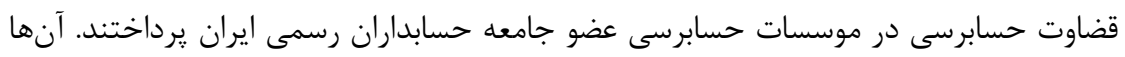

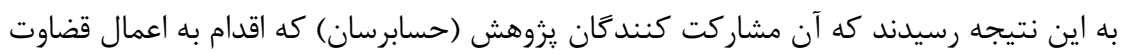

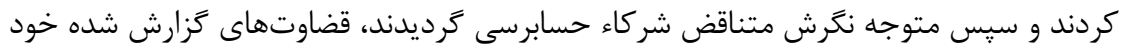


را در راستاى انطباق آن با نكرش آنها تحريف نمودند. مشاركت كنندكانى كه قبل از اعمال قضاوت

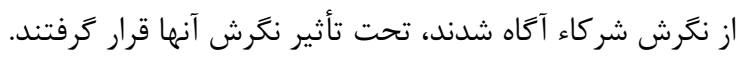

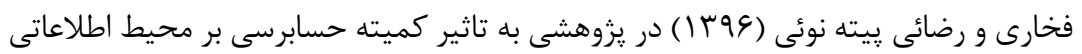

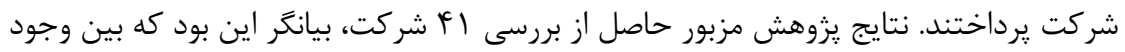

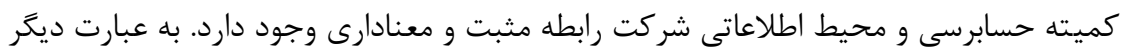

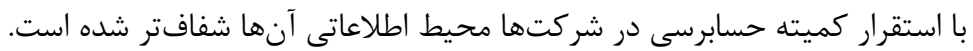

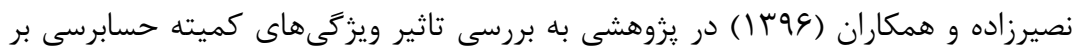

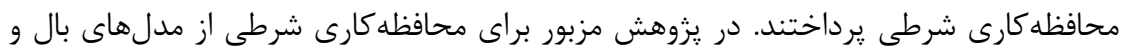

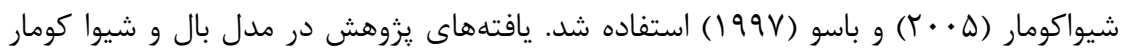

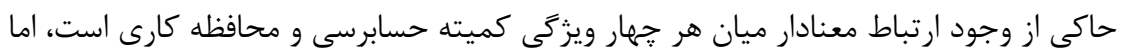

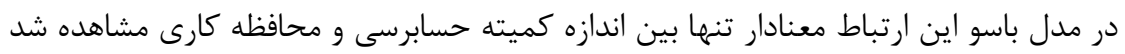

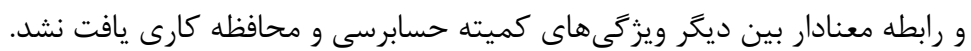

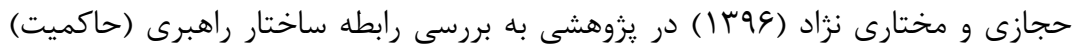

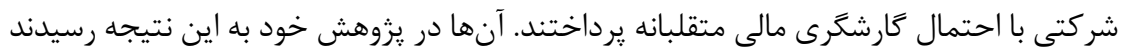

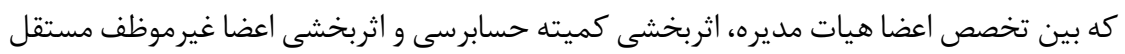

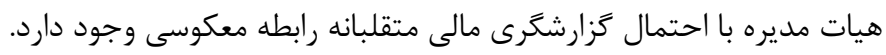

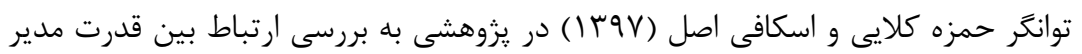

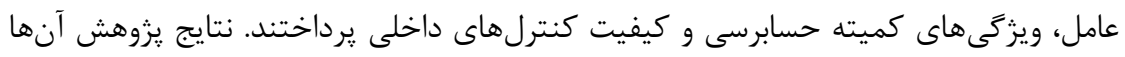
نشان داد كه از بين ويزگگى هاى كميته حسابرسى، تخصص مالى دالى اعضا و اندازه كميته حسابرسى،

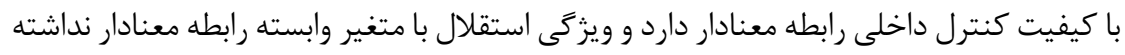

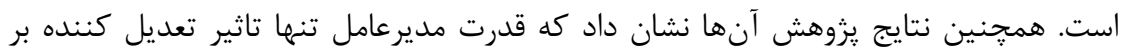
ارتباط بين اندازه كميته حسابرسى و كيفيت كنترل داخلى است ندان.

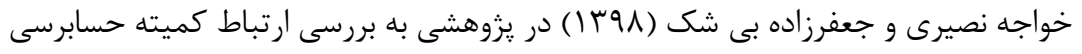

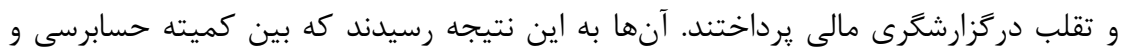

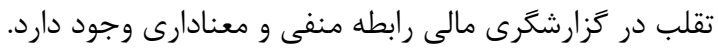

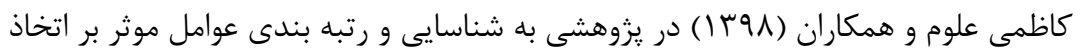

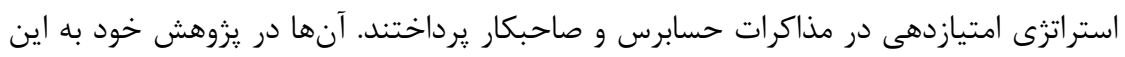

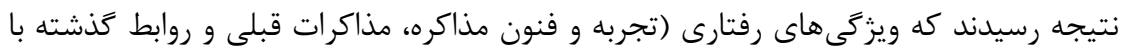

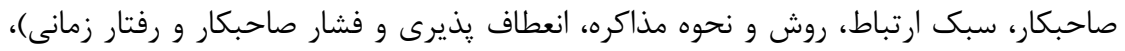

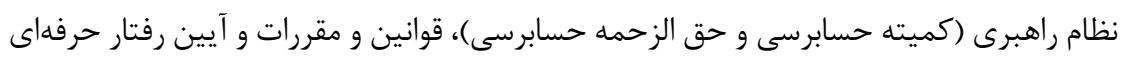


(اظهارنظر حسابرس، استقلال حسابرسان، قدرت و جانه زنى، رقابت در بازار حسابرسى و گردش

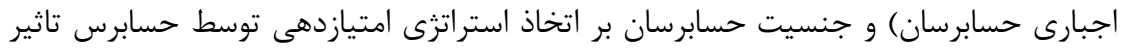
دارند. - n

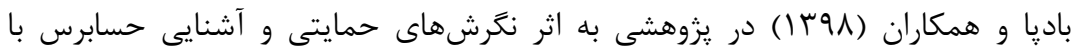

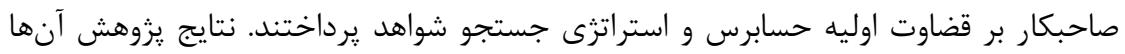

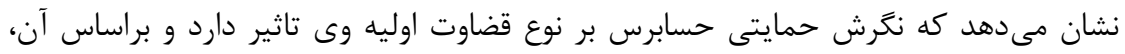

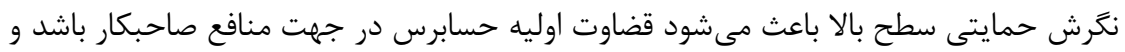

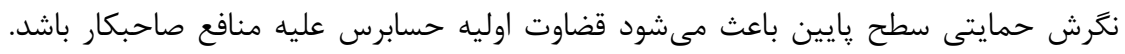

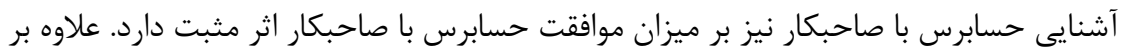

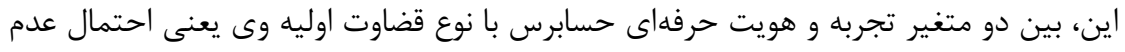

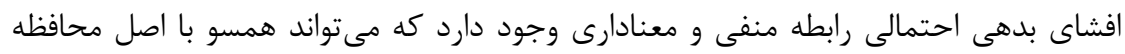

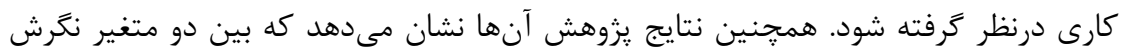
حمايتى حسابرس و نوع قضاوت اوليه حسابرس با استراتزى جستجوى شواهد نداند حسابرسى رابطه

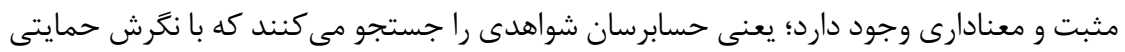

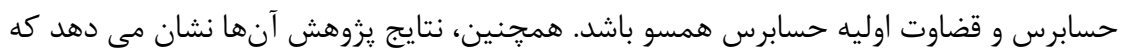

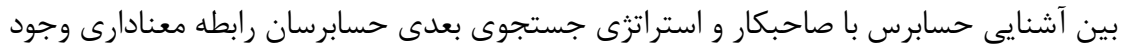

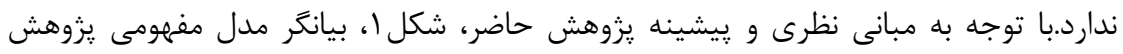

شكل ا- مدل مفهومى يزوهش

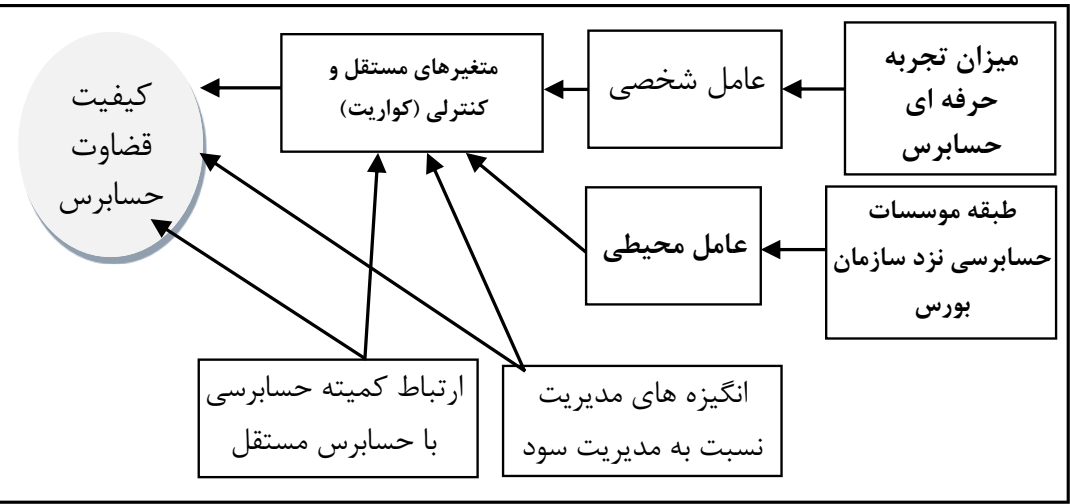




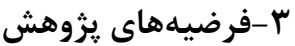

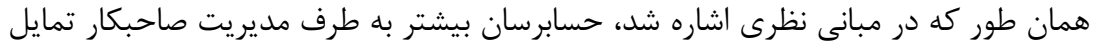

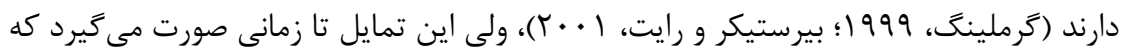

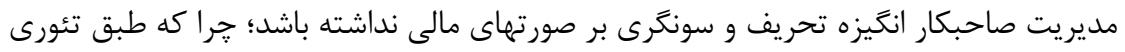

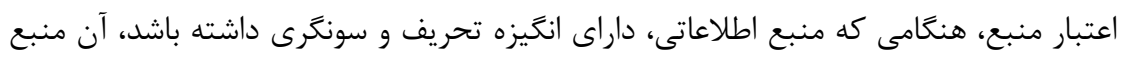

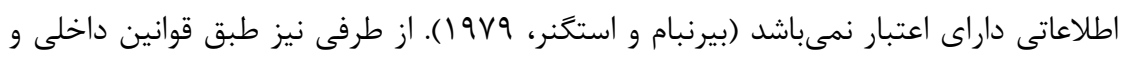
خارجى حسابرس و كميته حسابرسى بايستى با يكديكر در ارتباط باشند (منشور كميته

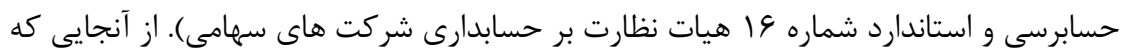

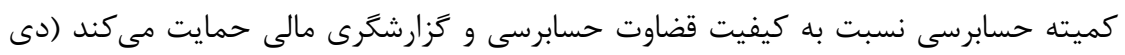

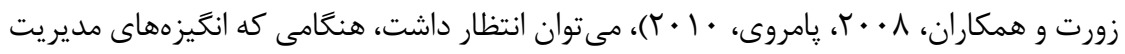

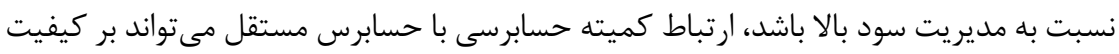

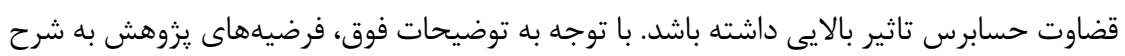
زير مطرح مى حَردند: فرضيه () انخيزههاى مديريت نسبت به مديريت سود بر كيفيت قضاوت حسابرس تاثير مثبت و معنادارى دارد. فرضيه r) ارتباط كميته حسابرسى با حسابرس مستقل، بر كيفيت قضاوت حسابرس تاثير

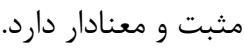

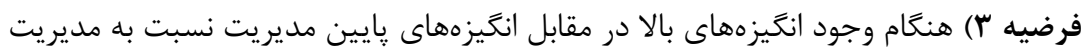

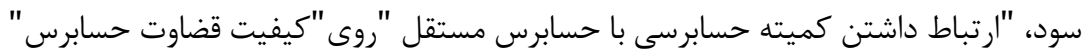
تاثير مثبت و معنادارى دارد.

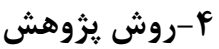

با توجه به هدف يزوهش، اين يزوهش از از لحاظ جمع آورى داده از نوع كمى و آزمايشى

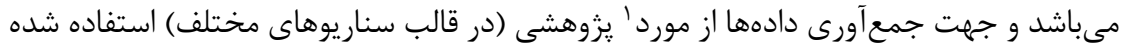

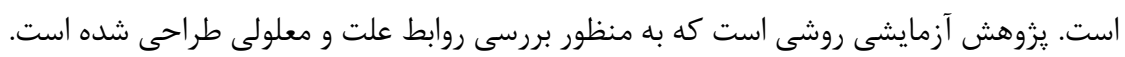

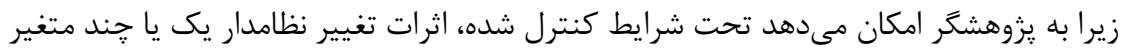

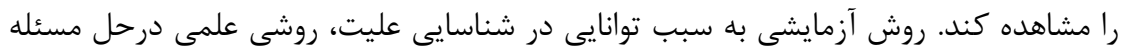

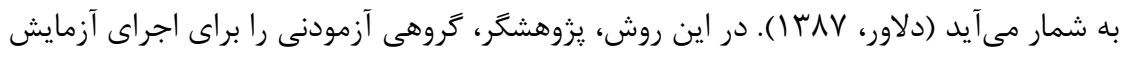

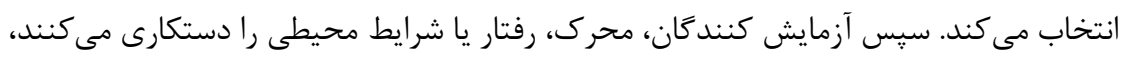

${ }^{1}$. Case 
سيس קگَنكى تاثير آن را در تغيير وضعيت و يا رفتار آزمودنى مورد مشاهده قرار مىدهند

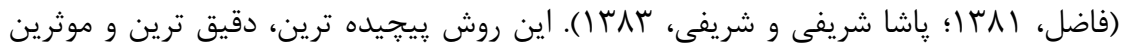

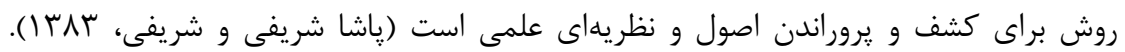
همجنين يزوهش حاضر از لحاظ تئورى، با توجه به اينكه ارتباطات بين متغيرهاى مستقل و وراى

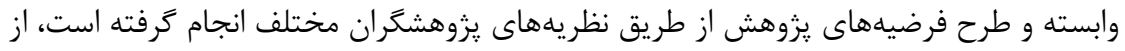

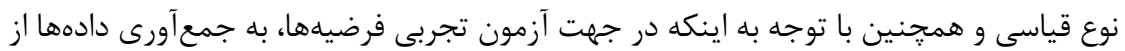

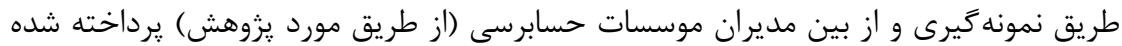

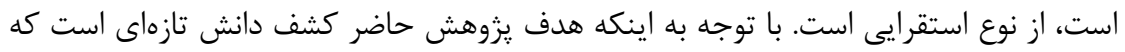

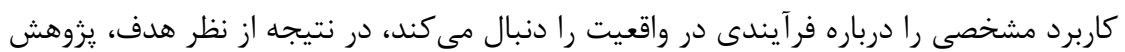
حاضر از نوع كاربردى مى آماشد.

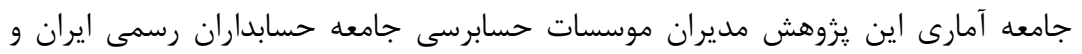

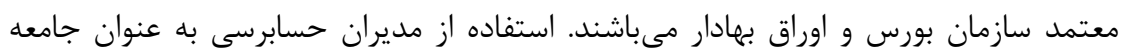
يزوهش، بدين علت است كه مديران حسابرسى بالاترين سمت جهت تصميم گيرى در عمليات

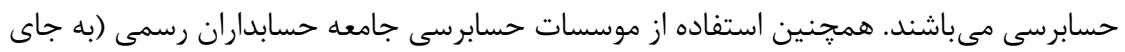

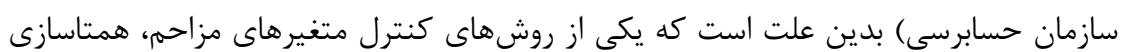

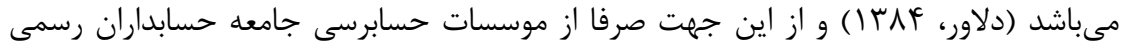

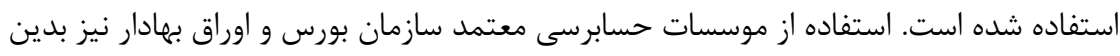

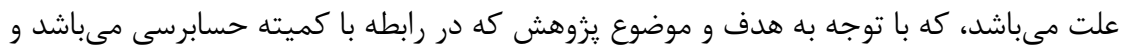

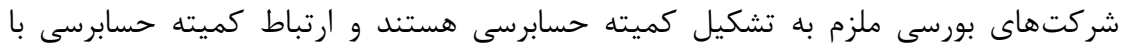
حسابرس مستقل ممكن است در اين شركتها صورت گيرد، از اين رو، از مدئ مديران مدان موسسات

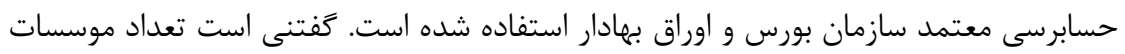

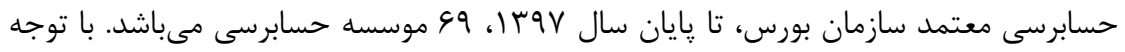

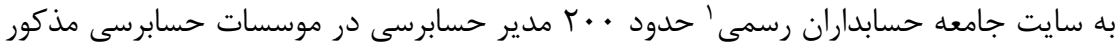

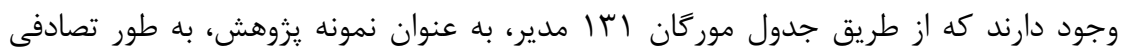

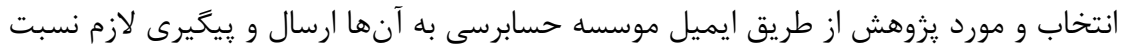

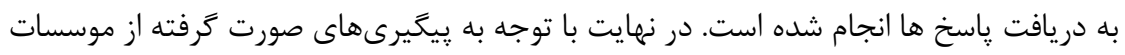

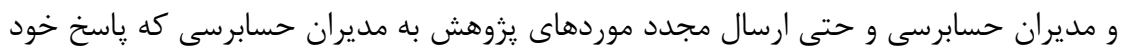

${ }^{1}$. http://www.iacpa.ir/\%D8\%A7\%D9\%85\%D9\%88\%D8\%B1-

\%D8\%A7\%D8\%B9\%D8\%B6\%D8\%A7/\%D9\%81\%D9\%87\%D8\%B1\%D8\%B3\%D8\%AA-

\%D9\%85\%D9\%88\%D8\%B3\%D8\%B3\%D8\%A7\%D8\%AA-\%D8\%B1\%D8\%B3\%D9\%85\%DB\%8C 


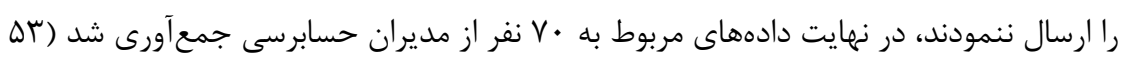

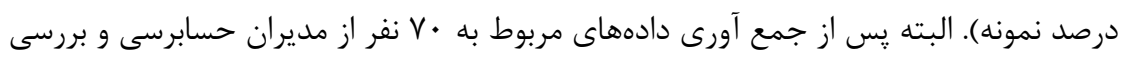

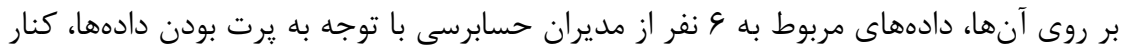

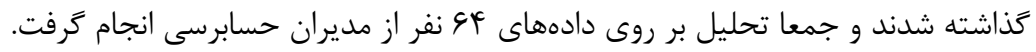

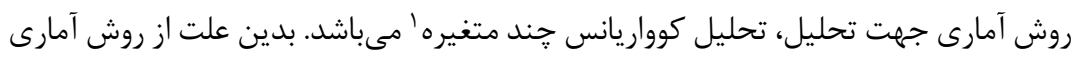

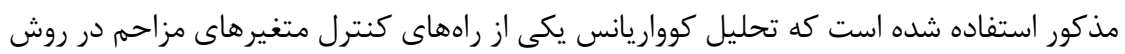

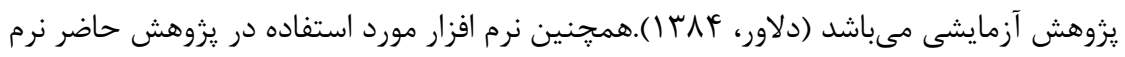

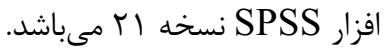

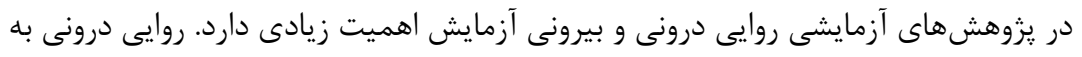

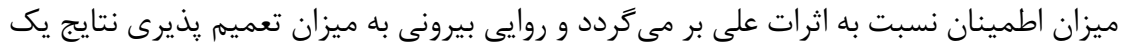

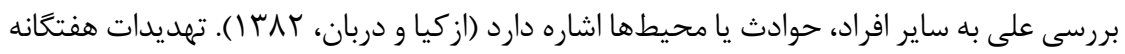

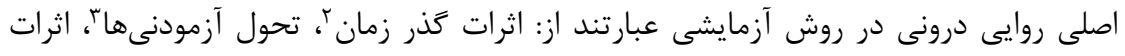

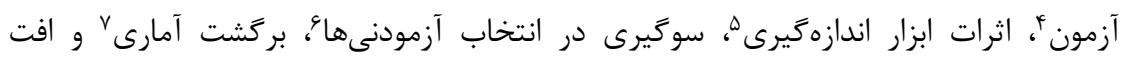

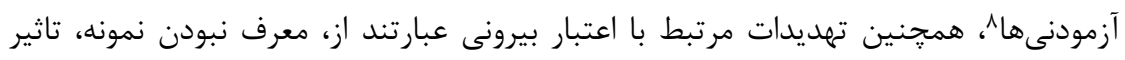

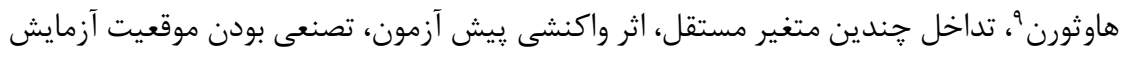

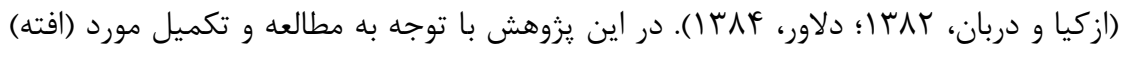

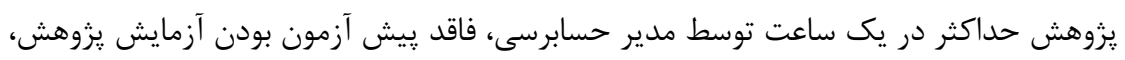

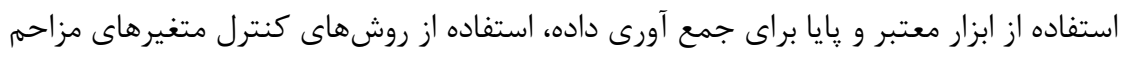

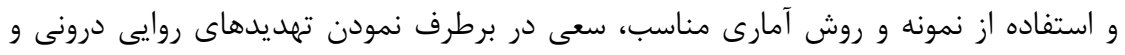
برخى تهديدهاى روايى بيرونى يزوهش شده است أمان.

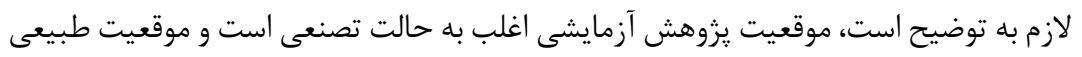

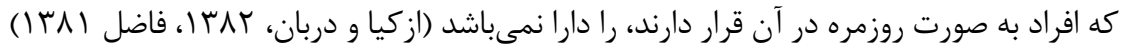

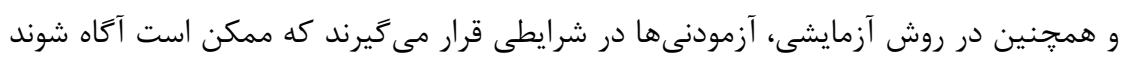

${ }^{1}$ MANCOVA

${ }^{2}$ Effects Of History

${ }^{3}$ Maturation

${ }^{4}$ Testing

${ }^{5}$ Instrumentation

${ }^{6}$ Selection

${ }^{7}$ Statistical Regression

${ }^{8}$ Morality

9 Hawthorne 


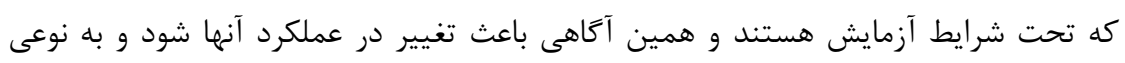

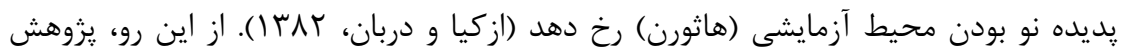

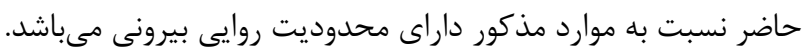

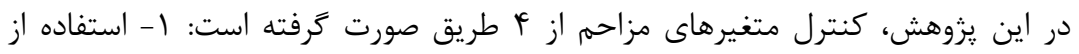

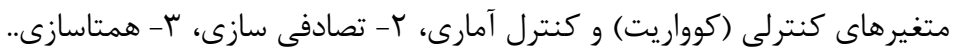
عوامل اثر گذار بر \كيفيت قضاوت و تصميم گيرى"، در سه عامل شخصى، فر آيندى و محيطى

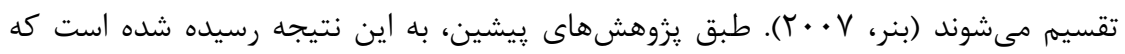

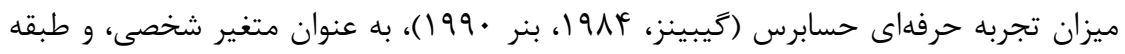

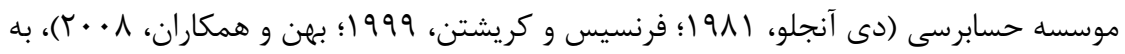
عنوان متغير محيطى، تاثير زيادى بر كيفيت قضاوت حسابرس دارد. از اين رو، طبق شرايط يزوهش از متغيرهاى كنترلى ميزان تجربه حرفهاى مدير حسابرسى (به عنوان متغير شخصى) و طبقه موسسه حسابرسى نزد سازمان بورس و اوراق بهادار (به عنوان متغير محيطى)، استفاده مئه شده است. در راستاى استفاده از متغيرهاى كنترلى مذكور، در اين يزوهش از روش رو آمارى تحليل

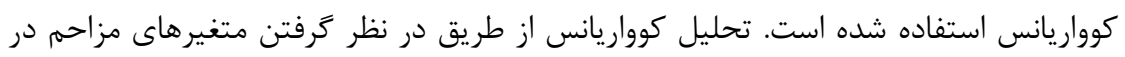

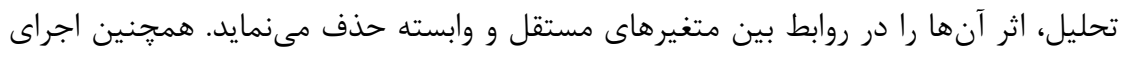

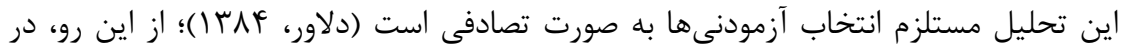
آزمايش اين يزوهش، از روش تصادفى سازى استفاده شده است. تصادفى سازى نيز به قرار دادن

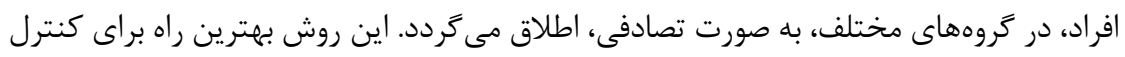

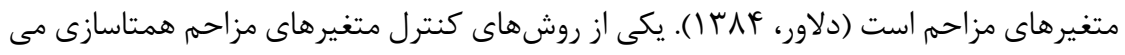

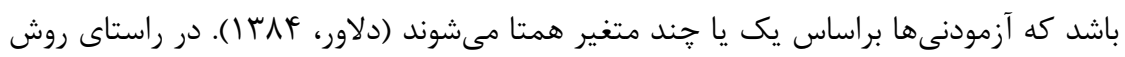
مذكور، در اين يزوهش با توجه به تفاوت كيفيت حسابرسى بين موسسات حسابرسى خصوصى و

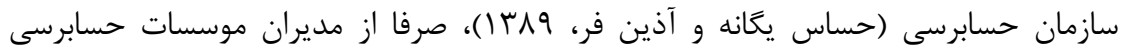
خصوصى (موسسات حسابرسى تحت نظارت جامعه حسابداران رسمى ايران) استفاده شده است.

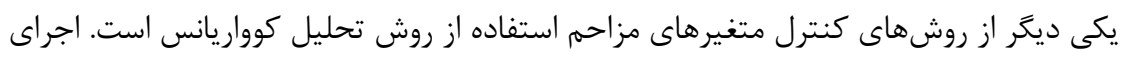

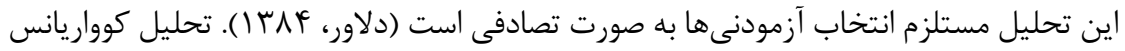

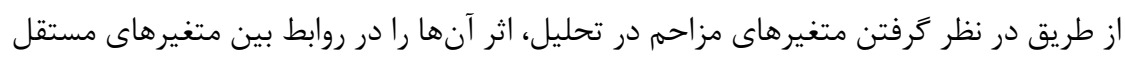

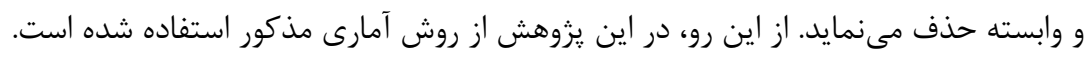




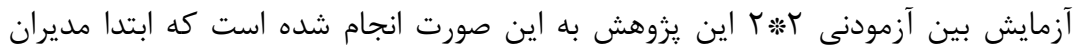

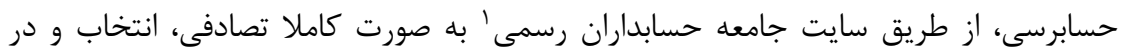

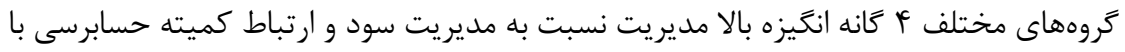

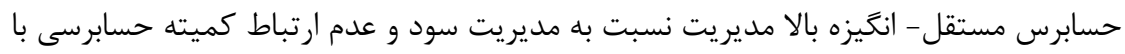

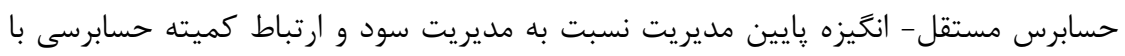

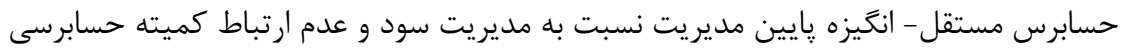

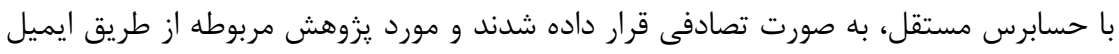

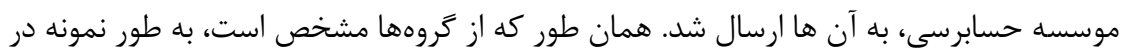

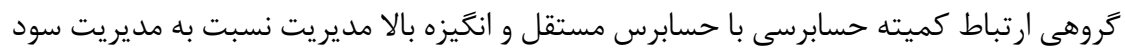

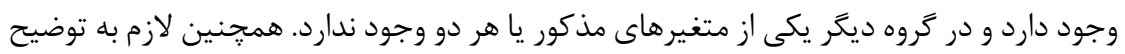

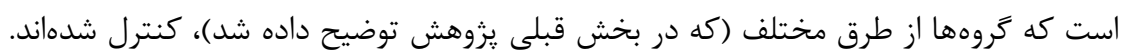

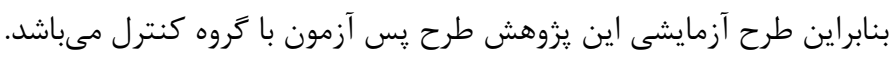

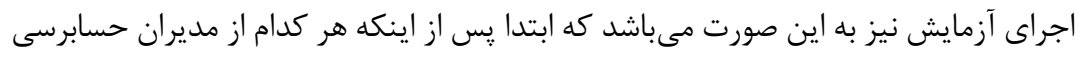

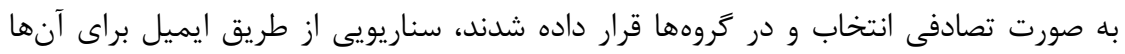

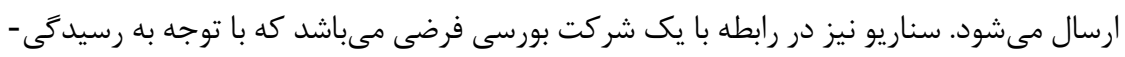

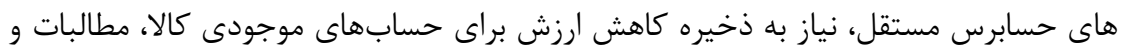

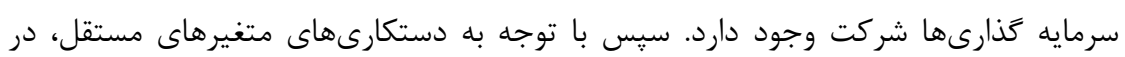

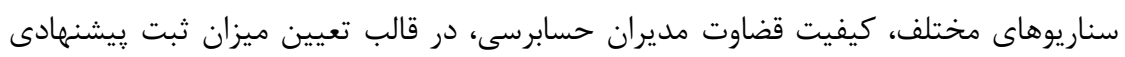

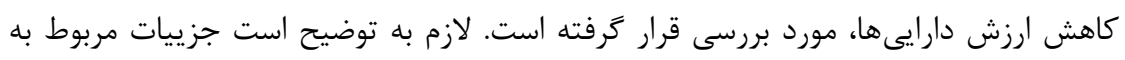

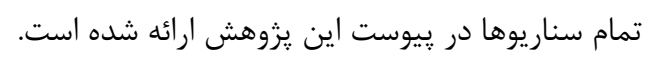

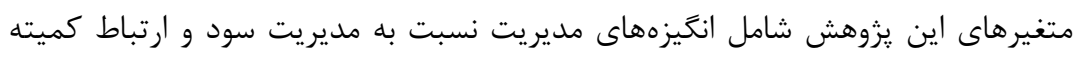

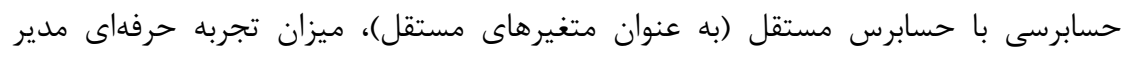

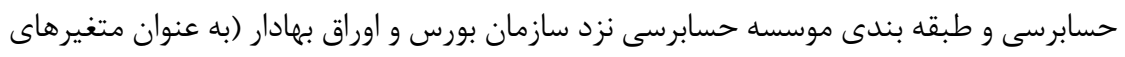

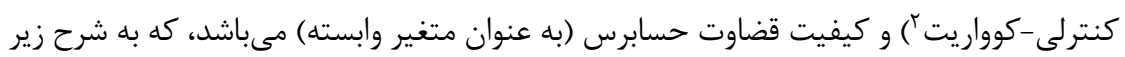

$$
\text { تعريف مى شوند: }
$$

${ }^{1}$ http://www.iacpa.ir/\%D8\%A7\%D9\%85\%D9\%88\%D8\%B1\%D8\%A7\%D8\%B9\%D8\%B6\%D8\%A7/\%D9\%81\%D9\%87\%D8\%B1\%D8\%B3\%D8\%AA-

\%D9\%85\%D9\%88\%D8\%B3\%D8\%B3\%D8\%A7\%D8\%AA-\%D8\%B1\%D8\%B3\%D9\%85\%DB\%8C

2 Covariate 
انغيزههاى مديريت نسبت به مديريت سود:

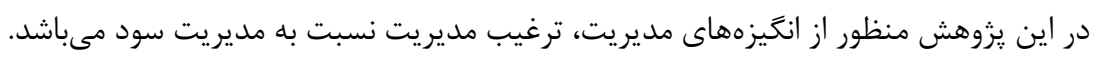

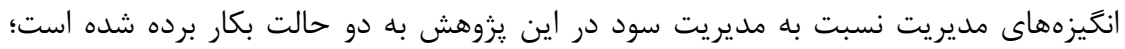

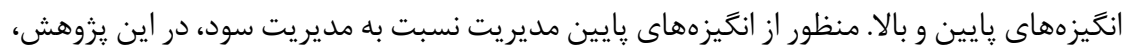

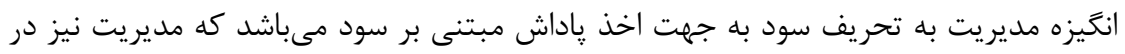

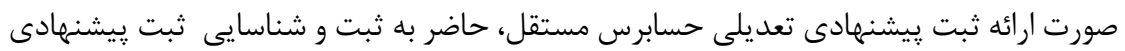
حسابرس در دفاتر و صورتهاى مالى مىباشد؛ كه به نوعى انخيزه شخصى مىباشد (رابرتسون،

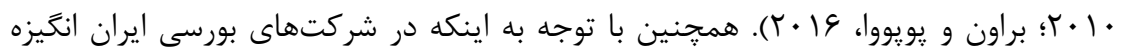

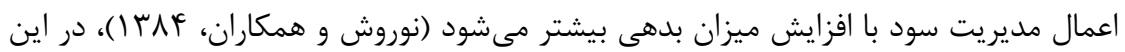
يزوهش براى انخَيزهاى بالاى مديريت نسبت به مديريت سود، علاوه به دريافت ياداش مبتنى

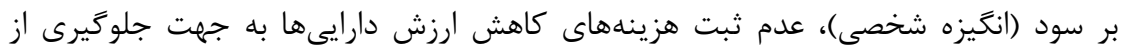
مشكلات قرارداد بدهى تعريف شده است (انخيزه شركتى) كه مديريت نيز اصرار بر عدم صدور ثبت يِشنههادى حسابرس دارد؛ كه به نوعى علاوه بر انخيزه شخصى شامل انگيزه شركتى مديريت

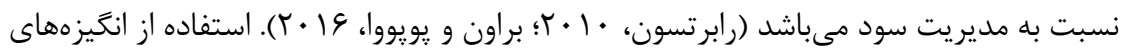
مديريت سود طبق يزوهش هاى خارجى ييش كفته در يروهش حاضر، بدين علت مىباشد كه انخيزه مديريت سود در ايران و ساير كشورها مشابه و نزديك است (مشايخ و همكاران، بوسا). در نهايت، با توجه به توضيحات فوق، اين متغير، در موردهاى يروهش، طى سنى سناريوهاى مختلف،

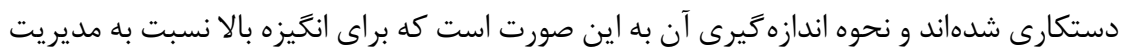

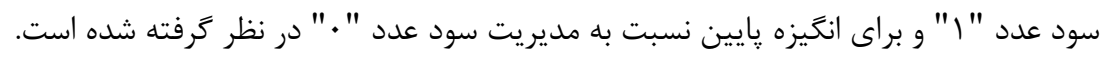
ارتباط كميته حسابرسى با حسابرس مستقل:

در اين يزوهش ارتباط كميته حسابرسى با حسابرس مستقل، به دو صورت وجود و عدم وجود ارتباط مذكور، در موردهاى يزوهش، طى سناريوهاى مختلف، مورد دستكارى قرار گرفته است. در زمان وجود ارتباط كميته حسابرسى با حسابرس مستقل، به مدير حسابرسى مستقل، علاوه بر مشخصات اعضاى كميته حسابرسى شركت، بيان شده است كه "كميته حسابرسى اين شركت كت بر فرآيند و كيفيت گزارشگرى مالى تمركز دارد و با مدير حسابرسى جلسهاى تشكيل مى مهدد و از مدير حسابرسى انتظار دارد كه هر تعديل حسابى كه در عمليات حسابرسى كشف شده، از طرف حسابرس مستقل به مديريت شركت ييشنهاد شود و هيج ثبت تعديل حسابى از طرف حسابرس جشم يوشى نشود". در زمان عدم وجود ارتباط نيز صرفا مشخصات اعضاى كميته

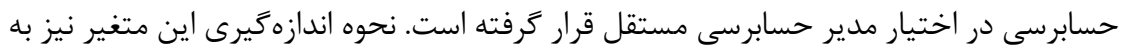


دكتر نيك بخت و حسين يور، تاثير " انكَيزه هاى مديريت نسبت به مديريت سود" و ...

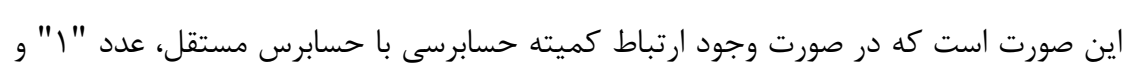

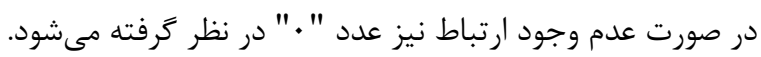

متغيرهاى كنترلى (كوواريت):

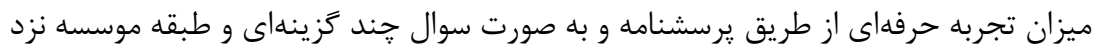

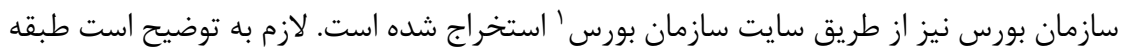

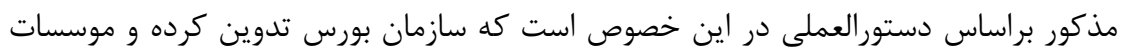

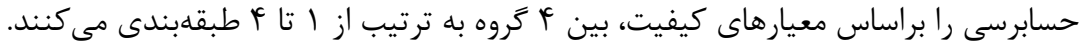

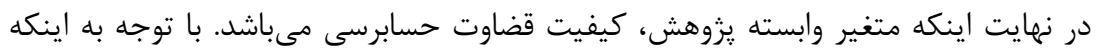

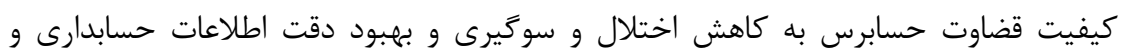

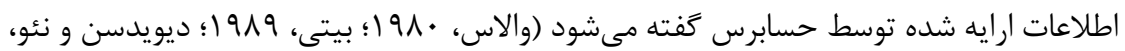

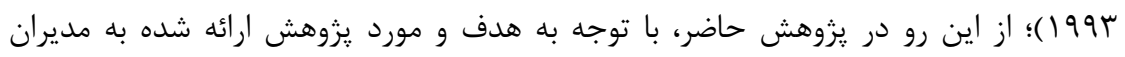

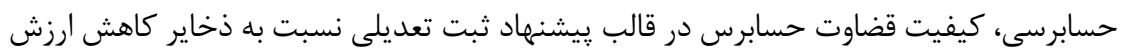

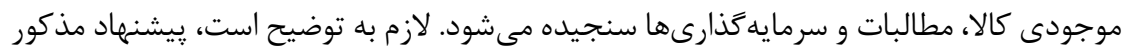

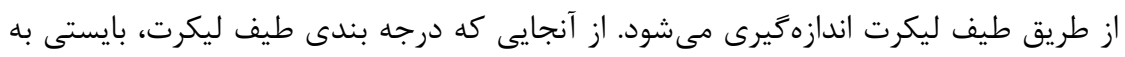

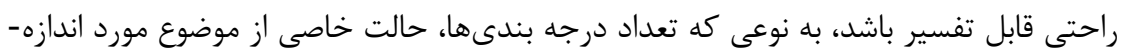

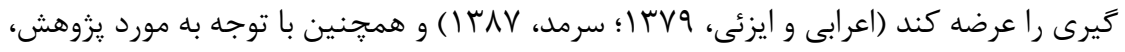

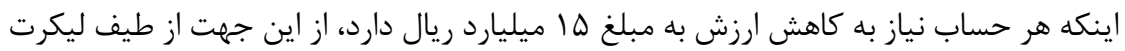

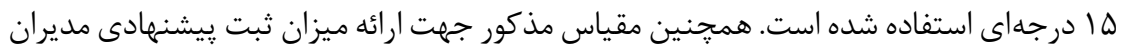

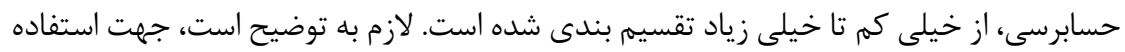

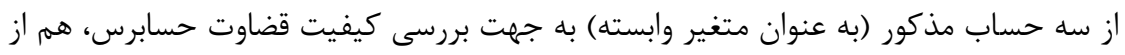

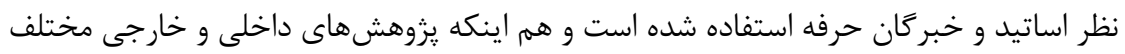

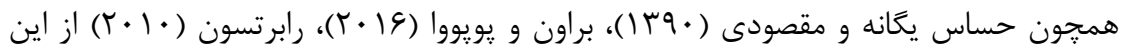

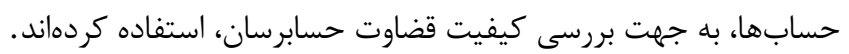

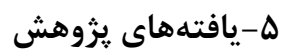

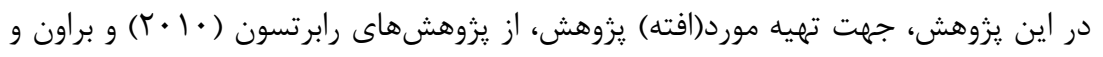

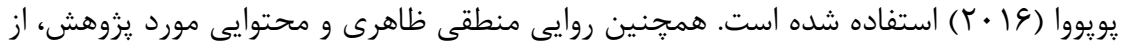

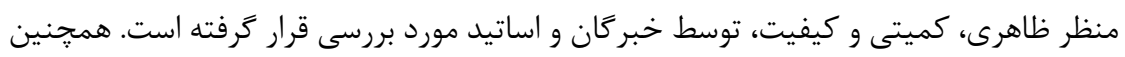

${ }^{1}$. https://www.seo.ir/Page/-wfhysKZkECb5EULXlycA==/\%D8\%AD\%D8\%B3\%D8\%A7\%D8\%A8\%D8\%B1\%D8\%B3\%D 8\%A7\%D9\%86-\%D9\%85\%D8\%B9\%D8\%AA\%D9\%85\%D8\%AF 
جهت بررسى يايايى ابزار يزوهش از آزمون آلفاى كرونباخ استفاده شده است. طبق محاسبات نرم

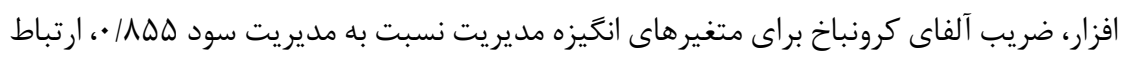

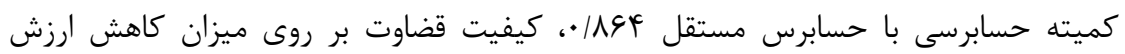

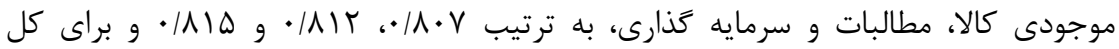

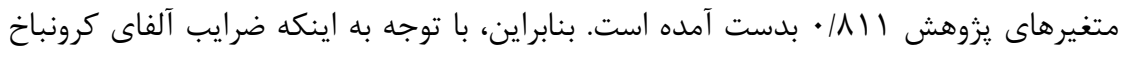

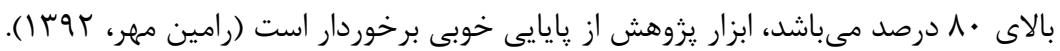

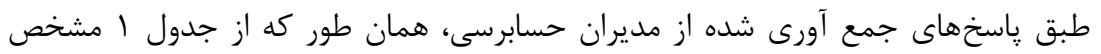

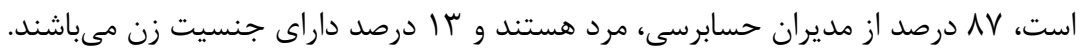
جدول ا- توزيع فراوانى مديران حسابرسى بر اساس جنسيت درديت

\begin{tabular}{|c|c|c|c|}
\hline درصد & فراوانى & كروه & متغير \\
\hline$\Lambda \mathrm{V}$ & $\Delta \varphi$ & مرد & \multirow[t]{2}{*}{ جنسيت } \\
\hline $1 \pi$ & $\wedge$ & زن & \\
\hline $1 \ldots$ & $g \varphi^{f}$ & & جمع \\
\hline
\end{tabular}

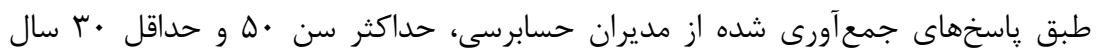

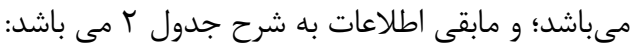
جدول r- آمار توصيفى سن مدير بـ باند: حسابرسى

\begin{tabular}{|c|c|}
\hline سن & \\
\hline r山 & ميانگين \\
\hline$r / T$ & انحراف معيار \\
\hline$\Delta$. & بيشترين \\
\hline$r$. & كمترين \\
\hline
\end{tabular}

طبق ياسخهاى جمع آورى شده از مديران حسابرسى، همان طور كه از جدول r مشخص

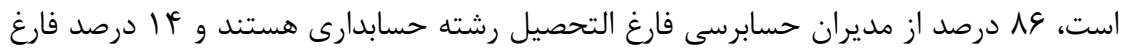
التحصيل ساير رشتهها (همجِون مديريت مالى درانى) هستند.

\begin{tabular}{|c|c|c|c|}
\hline درصد & فراوانى & كروه & متغير \\
\hline$\wedge \varepsilon$ & $\Delta \Delta$ & حسابدارى & \multirow{2}{*}{ رشته تحصيلى } \\
\hline If & 9 & ساير رشته ها & \\
\hline $1 \ldots$ & $G F$ & جمع & \\
\hline
\end{tabular}


ميزان تحصيلات ياسخكويان به صورت جند كزينهاى از مقطع كارشناسى الى دكترى يرسيده

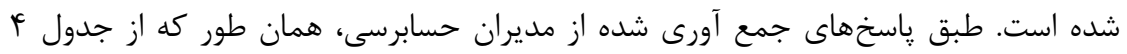

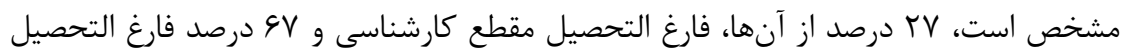

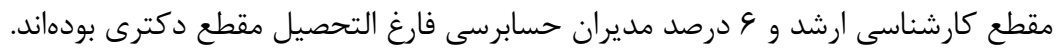

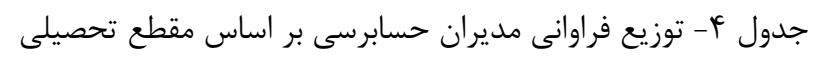

\begin{tabular}{|c|c|c|c|}
\hline درصد & فراوانى & كروه & متغير \\
\hline TV & IV & كارشناسى & \multirow{3}{*}{ رشته تحصيلى } \\
\hline $9 V$ & Fr & كارشناسى ارشد & \\
\hline 9 & i & ل دكترى & \\
\hline $1 \cdots$ & st & جمع & \\
\hline
\end{tabular}

طبق ياسخهاى جمع آورى شده از مديران حسابرسى، تمام مديران حسابرسى تجربه جلسه

$$
\text { با كميته حسابرسى داشتند. }
$$

$$
\text { a }
$$

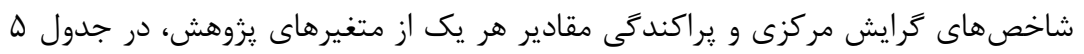
نشان داده شده است.

\begin{tabular}{|c|c|c|c|c|c|}
\hline ميزان تجربه & طظوسته بندى از & كاهش ارزش ميت سرمايشنهادى & ي ميشنهادي كاهش ثبت & 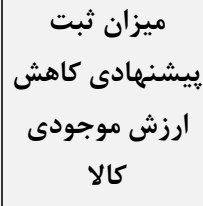 & \\
\hline$r / 19$ & $1 / 94$ & $9 / 11$ & $1 . / 14$ & $1 . / 1 \mathrm{~V}$ & ميانگين \\
\hline 1 & 1 & $1 \cdot$ & 1 . & 1 . & ميانه \\
\hline r & 1 & 1 . & $1 \cdot$ & 1 . & مد \\
\hline$\cdot / \Lambda V$ & $\cdot \mid \wedge \Delta$ & $r / \cdot \Lambda$ & r/Ir & $r / \cdot q$ & |نحراف \\
\hline 1 & 1 & $r$ & r & $r$ & حداقل \\
\hline f & r & 10 & 10 & 10 & حداكثر \\
\hline . & $1 / \pi$ &.$- / 4 T$ & $-\cdot \mid \Delta \varphi$ & -.19 & جولغى \\
\hline-.191 & $1 / \cdot \Delta$ & . & $\cdot|\Delta|$ & $\cdot 191$ & كشيدگى \\
\hline
\end{tabular}

جدول ه- آمار توصيفى 
همان طور كه از جدول ه مشخص است، ميانخين متغير كيفيت قضاوت حسابرسان جهت ارائه

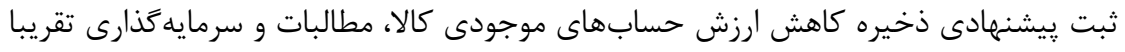

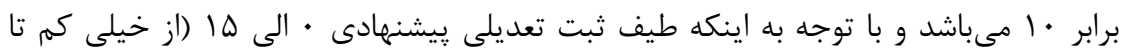

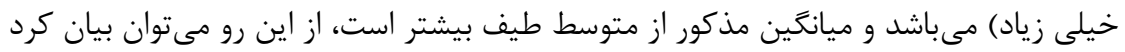

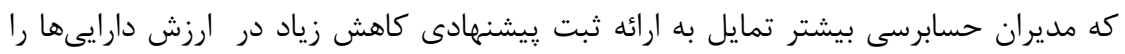

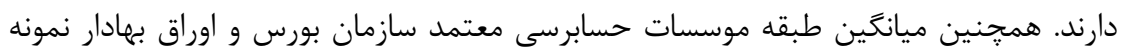

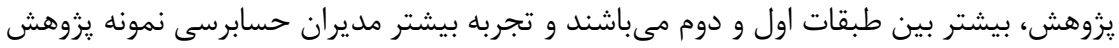

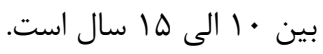

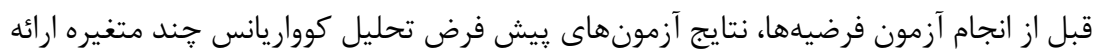

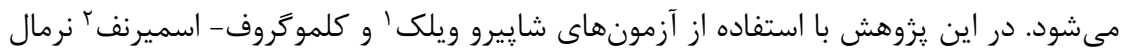

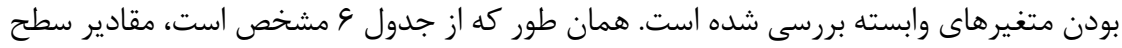

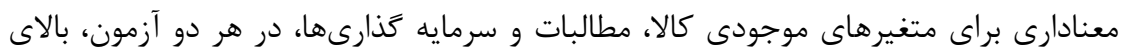

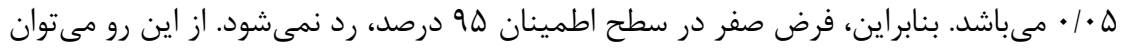

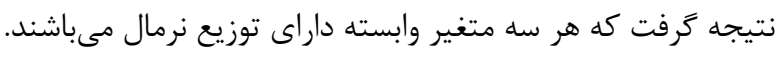

جدول \&- آزمون شإِيرو ويلك و كلموكروف اسميرنوف

\begin{tabular}{|c|c|c|c|c|c|c|}
\hline \multirow[b]{2}{*}{ متغيرها } & \multicolumn{3}{|c|}{ شإِيرو ويلك } & \multicolumn{3}{|c|}{ كولموگروف-اسميرنوف } \\
\hline & آماره & تعداد & معنى & آماره & تعداد & سطح \\
\hline مبت ميفيت قضاوت نسبت به ميزان & $\cdot / 1 \cdot f$ & $g 4$ & $\cdot 1 \cdot \Lambda \cdot$ & $1 / 194$ & gr & .1119 \\
\hline 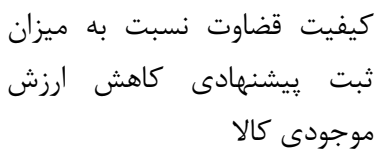 & (. & $g 4$ & $\cdot / T \cdot \cdot$ & $1 / 111$ & $g \varphi^{f}$ & .1199 \\
\hline مبت ميفيت قضاوت نسبت به ميزان & .1 .91 & $g 4$ & $\cdot / T \cdot \cdot$ & $1 / \cdot \Delta \varphi$ & $g f$ & $\cdot / T / D$ \\
\hline
\end{tabular}

${ }^{1}$. Shapiro- Wilk

${ }^{2}$. Kolmogorov- Smirnov 
همجنين همان طور كه از آزمون Box's M در جدول Vشخص است، مقدار معنادارى بالاى مشاي

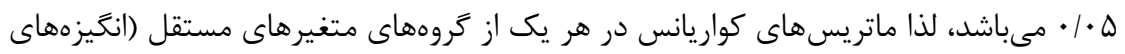

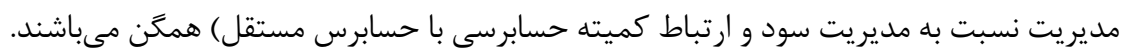

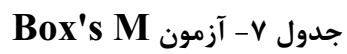

\begin{tabular}{|l|l|}
\hline Box's M & $11 / 9$ rr \\
\hline F & $1 / V T V$ \\
\hline df1 & 9 \\
\hline df2 & $9 \Delta r \cdot / V \Delta D$ \\
\hline sig. & $\bullet / 11 \cdot$ \\
\hline
\end{tabular}

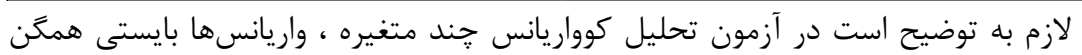

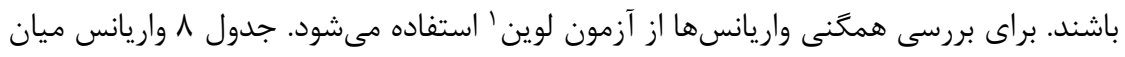

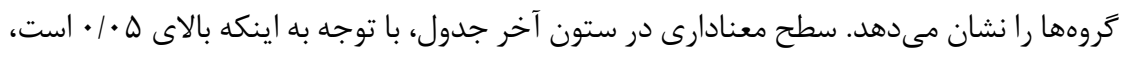

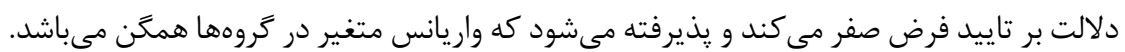
جدول ^- نتايج آزمون همخنى واريانس

\begin{tabular}{|c|c|c|c|c|}
\hline & آماره F F & df1 & df2 & سطح معنادارى \\
\hline قضاوت بر موجودى كالا & $\cdot / r v q$ & r & q. & $\cdot / V 9 \Lambda$ \\
\hline قضاوت بر مطالبات & • & r & 4. &.$/ V 99$ \\
\hline قضاوت بر سرمايه كذارى & . / KFe & $r$ & 4. & ./V9r \\
\hline
\end{tabular}

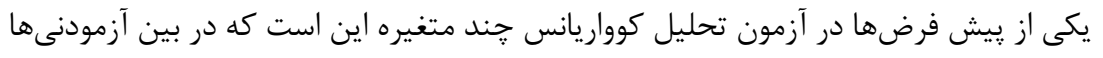

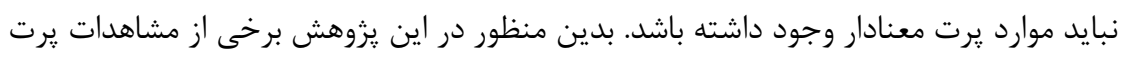

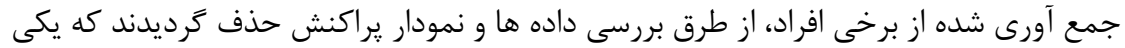

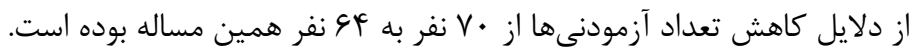

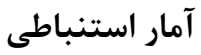

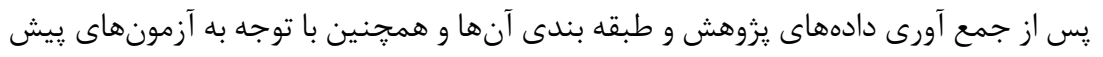

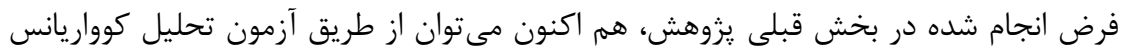

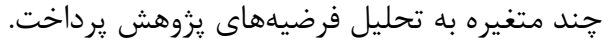

${ }^{1}$. Levene 


\begin{tabular}{|c|c|c|c|c|c|c|c|}
\hline \multicolumn{8}{|c|}{ جدول 9- آزمون تحليل كوواريانس جند متغيره } \\
\hline \multicolumn{2}{|l|}{ منبع } & $\begin{array}{l}3.2 \\
\vdots \\
w \\
w \\
\xi \\
3 \\
3 \\
3\end{array}$ & $\frac{3}{9}$ & $\begin{array}{ll}3 & \\
y & 2 \\
3: & 2 \\
3 & 2\end{array}$ & Ta & $\frac{3}{3}$ & $\begin{array}{l}\overline{3} \\
\frac{2}{3} \\
\frac{2}{3}\end{array}$ \\
\hline \multirow{3}{*}{ مدل تصحيح شده } & موجودى كالا & $\Delta \cdot q / r \cdot r^{a}$ & $\Delta$ & $1 \cdot / \wedge \varepsilon$. & GP/TDI & $1 \cdots$ & - $/ A F V$ \\
\hline & مطالبات & $\Delta Y G / \Delta \mid \varepsilon^{b}$ & $\Delta$ & $1 \cdot / r \cdot r$ & $G \Lambda / F \Delta S$ & $1 \cdots$ & $\cdot 1 \wedge \Delta \Delta$ \\
\hline & سرمايه گذارى & 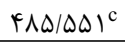 & $\Delta$ & $9 V / 11$. & $01 / 111$ & $1 \cdots$ & $\cdot|\Lambda| \Delta$ \\
\hline \multirow{3}{*}{ 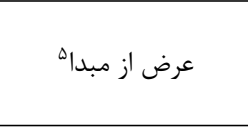 } & موجودى كالا & rII/rra & 1 & rI/rrq & $1 r / \Delta \cdot \Lambda$ & $1 \cdots$ & $.199 \mathrm{~V}$ \\
\hline & مطالبات & $r \cdot r / V \cdot r$ & 1 & $r \cdot / V \cdot r$ & IT/FTD & $1 \cdots$ & .1990 \\
\hline & سرمايه گذارى & $198 / 449$ & 1 & $19 / 449$ & $1 \mathrm{~V} / \mathrm{G} \cdot \mathrm{G}$ & $1 \cdots$ & $\cdot 19 \cdot r$ \\
\hline \multirow{3}{*}{ طبقه بندى موسسه } & موجودى كالا & FV/VAT & 1 & FV/VAT & $r \cdot / 19 \Lambda$ & $1 \cdots$ & - MET \\
\hline & مطالبات & $F \in / K V F$ & 1 & $F \varepsilon / T V F$ & $r \cdot / l f v$ & $1 \cdots$ & . MFt \\
\hline & سرمايهَذارى & rr/vfq & 1 & rr/VFq & IV/VGK & $1 \cdots$ & . /TMF \\
\hline \multirow{3}{*}{ تجربه حرفهاى مدير } & موجودى كالا & $r \varepsilon / V \cdot q$ & 1 & $r \varepsilon / V \cdot q$ & $19 / \Lambda V^{F}$ & $1 \cdots$ & . RTD \\
\hline & مطالبات & $r q / 19 \Lambda$ & 1 & $r q / 19 \Lambda$ & IN/৭६Y & $1 \cdots$ & $\cdot / T \cdot r$ \\
\hline & سرمايه َذارى & $r \Delta / 991$ & 1 & $r \Delta / 991$ & IN/qFT & $1 \cdots$ & - MYG \\
\hline \multirow{3}{*}{ انگَيزه هاى مديريت } & موجودى كالا & $0 . / 110$ & 1 & $0 . / 110$ & rI/99. & $1 \cdots$ & $\cdot / r \Delta r$ \\
\hline & مطالبات & $\Delta T / F \cdot \Delta$ & 1 & $\Delta T / F \cdot \Delta$ & $r F / . G \Lambda$ & $1 \cdots$ & $\cdot / r V$. \\
\hline & سرمايه َذارى & $p V / q \cdot \Lambda$ & 1 & $p V / q \cdot \Lambda$ & $r \Delta / r \mid \Delta$ & $1 \cdots$ & $\cdot / r \cdot r$ \\
\hline \multirow{3}{*}{ ارتباط حمابرس مستقل حسابرسى } & موجودى كالا & rN/qVT & 1 & rN/qVT & TF/GTI & $1 \cdots$ &.$/ 491$ \\
\hline & مطالبات & ( & 1 & r & $r \Delta / \Delta V$. & $1 \cdots$ & $\cdot \pi \cdot 9$ \\
\hline & سرمايه گذارى & rN/9AV & 1 & YN/9AV & $I \Delta / r \Delta V$ & $1 \cdots$ & $\cdot / \pi \cdot 1$ \\
\hline \multirow{3}{*}{ مديريت و ارتباط كابزيزه كميته } & موجودى كالا & N/FVT & 1 & N/EVT & $\Delta / T \Delta T$ & $1 \cdot T F$ & $\cdot 1 \cdot \wedge f$ \\
\hline & مطالبات & $1 . / 199$ & 1 & $1 . / 799$ & 9/994 & $1.1 \mathrm{~T}$ & $\cdot / 1 \cdot r$ \\
\hline & سرمايه َذارى & $10 / 9.9$ & 1 & $10 / 9.9$ & $\Lambda / r V I$ & $1 \cdots \Delta$ & $.11 T 4$ \\
\hline \multirow{3}{*}{ خطا } & موجودى كالا & $91 / 1 \cdot 1$ & $\Delta \Lambda$ & $1 / \Delta \wedge r$ & & & \\
\hline & مطالبات & $19 / \pi 19$ & $\Delta \Lambda$ & I/DrA & & & \\
\hline & سرمايه گذارى & $11 \cdot 1199$ & $\Delta \Lambda$ & $1 / 9 \ldots$ & & & \\
\hline \multirow{3}{*}{ جمع } & موجودى كالا & VTr/... & GF & & & & \\
\hline & مطالبات & $\vee 19 / \ldots$ & gf & & & & \\
\hline & سرمايه َذارى & $s \vee \Delta / \ldots$ & gf & & & & \\
\hline \multirow{3}{*}{ جمع تصحيح شده } & موجودى كالا & $9.1 / 1 \cdot 9$ & $9 \pi$ & & & & \\
\hline & مطالبات & GID/VTr & \& & & & & \\
\hline & سرمايه كذارى & $\Delta 9 \Delta / V \Delta$. & q & & & & \\
\hline
\end{tabular}

1 . Type III Sum of Squares

2. Mean Square

3 . Partial Eta Squared

4 . Corrected Model

5 . Intercept 


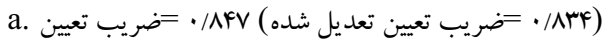

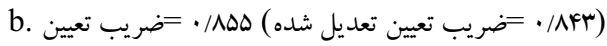

C. C/N99)

همان طور كه از جدول 9 مشخص است، متغير"انخيزههاى مديريت نسبت به مديريت سود" بر كيفيت قضاوت حسابرس (هر سه متغير وابسته) در سطح اطمينان هو درصد تاثير معنادارى دارد. همجنين با توجه به جدول · ا مشخص است كه ميانگين متغير كيفيت قضاوت مديران

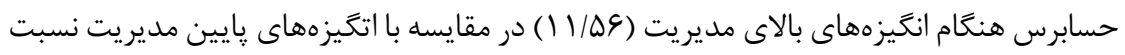
به مديريت سود (N/Dr) بيشتر است. از اين رو، فرضيه اول يثروهش تائيد مىشود. همجنين همان طور كه از جدول 9 مشخص است "ارتباط كميته حسابرسى با حسابرس مستقل" بر كيفيت قضاوت حسابرس در سطح اطمينان هو درصد تاثير معنادار دارد. همجنين طبق جدول مشخص است كه ميانگين كيفيت قضاوت مديران حسابرسى هنگام وجود ارتباط كميته حسابرسى با حسابرس مستقل (1/91/) بيش از زمانى است كه اين ارتباط وجود ندارد ( • (N/1).

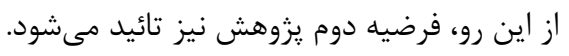

\begin{tabular}{|c|c|c|c|c|}
\hline & & \multicolumn{2}{|c|}{ انگيزههاى مديريت نسبت } & \multirow[t]{2}{*}{ كل } \\
\hline & & هايين & بالا & \\
\hline \multirow{2}{*}{ |ر ارتباط كميته حسابرسى با } & وجود & $1 \cdot / V V$ & $14 / 19$ & $11 / 91$ \\
\hline & عدم وجود & $G / T V$ & $9 / 94$ & $1 / 1$. \\
\hline \multicolumn{2}{|l|}{ كل } & $N / \Delta T$ & $11 / \Delta 9$ & 1. \\
\hline
\end{tabular}

همان طور كه از جدول II مشخص است، طبق آزمون تحليل كوواريانس جند متغيره، ، هنگام وجود انگيزههاى بالا در مقابل انخيزههاى يايين مديريت صاحبكار نسبت به مديريت سود، ارتباط كميته حسابرسى با حسابرس مستقل، تاثير معنادارى بر كيفيت قضاوت حسابرس دارد. همجنين يُّنين طبق جدول • ا مشخص است كه هنغام وجود ارتباط كميته حسابرسى با حسابرس مستقل، ميانگين متغير كيفيت قضاوت مديران حسابرسى، در زمان وجود انخيزههاى بالا (19/19) در مقايسه با حالتى كه انخيزههاى يايين مديريت نسبت به مديريت سود (VV/ • (1) وجود دارد، بالاتر

است. از اين رو فرضيه سوم يزوهش نيز تائيد مىشود. تحليل كوواريانس، ميانگين دو يا جند گروه مستقل، در متغير يا متغيرهاى وابسته را را مورد مقايسه قرار مى دهد و از اين طريق ميزان تاثير متغير مستقل را بر متغير وابسته بررسى مى كند.

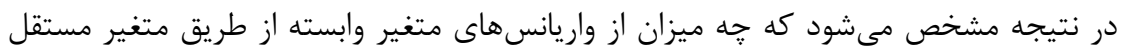


ايجاد شده است. از اين رو، ستون آخر جدول 9 نيز واريانس تبيين شده متغيرهاى وابسته از

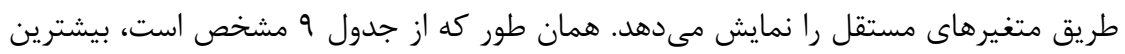

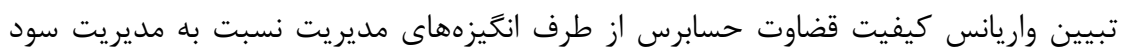

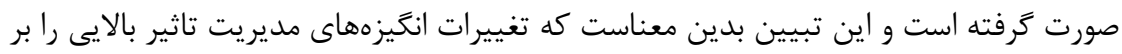
روى كيفيت قضاوت حسابرس مى كذارد.

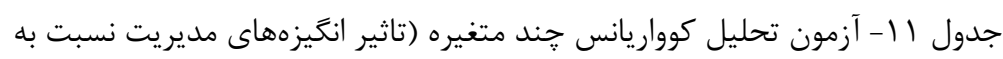

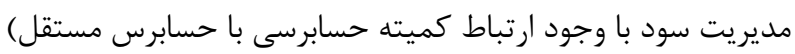

\begin{tabular}{|c|c|c|c|c|c|c|}
\hline \multicolumn{2}{|c|}{ منبع } & \multirow{2}{*}{\begin{tabular}{|c|} 
مربعات نوع \\
مجوم \\
$11 / 19 V$
\end{tabular}} & \multirow{2}{*}{ آزادى } & \multirow{2}{*}{ 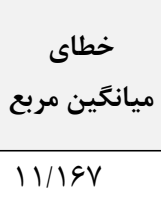 } & \multirow{2}{*}{ 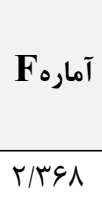 } & \multirow{2}{*}{ معنادارى } \\
\hline انغيزههاى & موجودى كالا| & & & & & \\
\hline مديريت & مطالبات & $1 \cdot 1019$ & 1 & $1 \cdot 1019$ & $r / 9 \Delta \Delta$ & $\cdot / \cdots$ \\
\hline صاحبكار & سرمايه گذارى & T/AFV & 1 & T/AFV & س & r \\
\hline
\end{tabular}

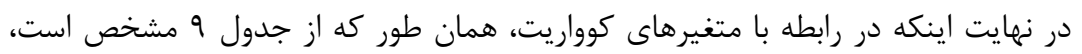

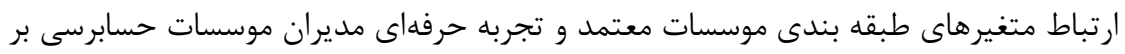

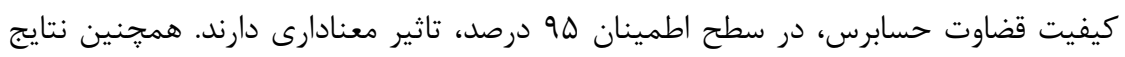

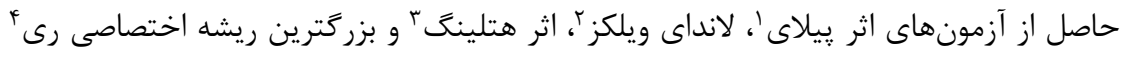

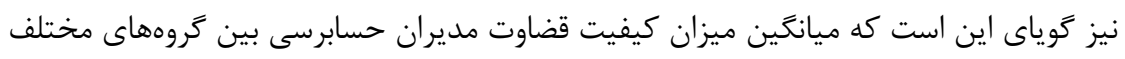

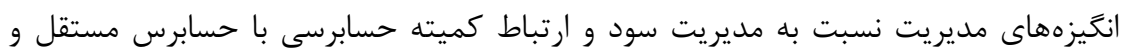
همجنين تعامل آنها تفاوت معنادارى وجود دارد.

\section{9-بحث و نتيجه كيرى}

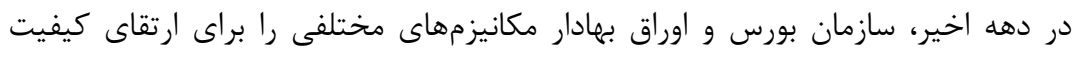

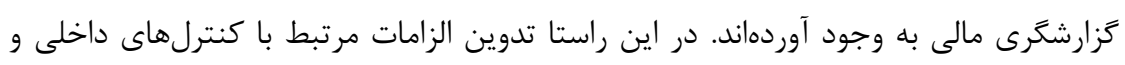

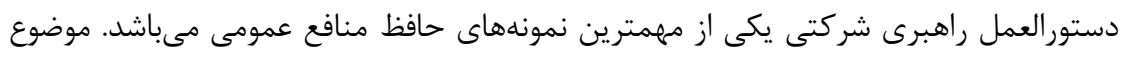

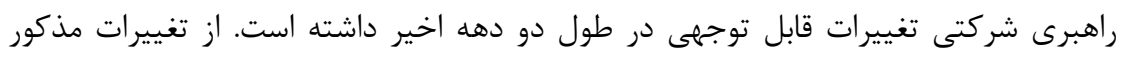

${ }^{1}$ Pillai's Trace

${ }^{2}$ Wilks' Lambda

${ }^{3}$ Hotelling's Trace

${ }^{4}$ Roy's Largest Root 
مىتوان به إيجاد نقش فعال كميته حسابرسى اشاره كرد. در سالهاى كذشته اهميت كميته

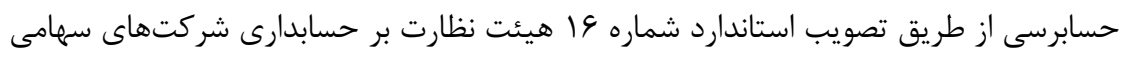

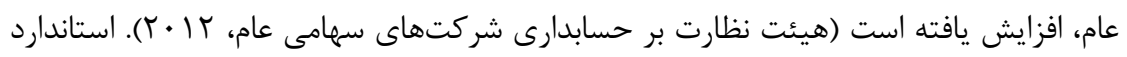

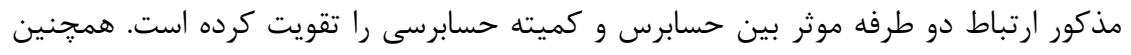

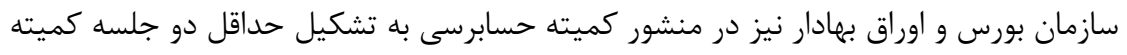

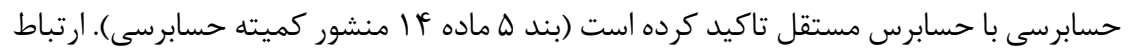

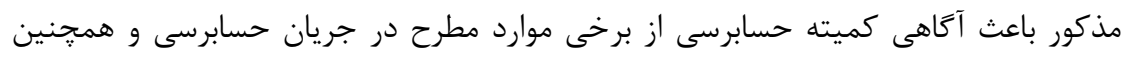

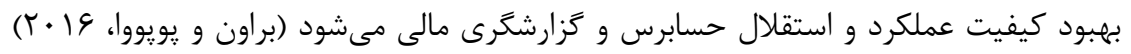

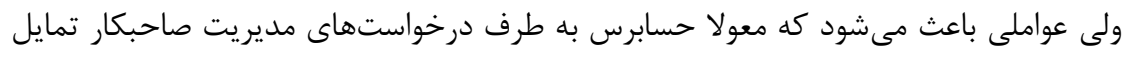

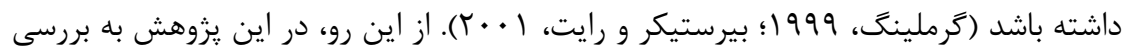
مكانيزم تاثير ارتباط كميته حسابرسى با حسابرس مستقل بر كيفيت قضاوت رابن حسابرس مستقل يرداخته شد.

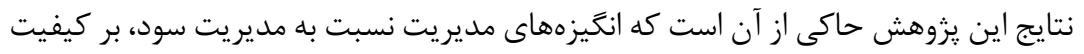

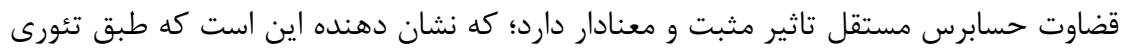

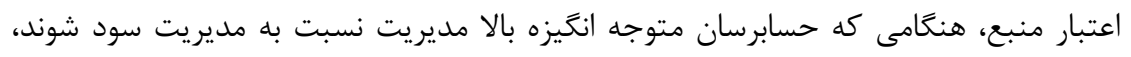

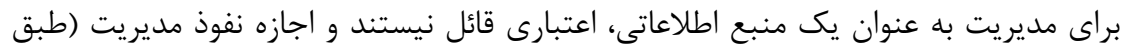

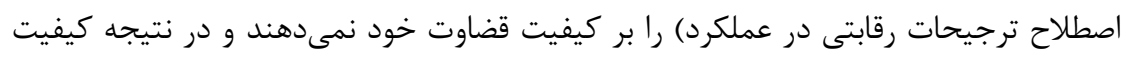

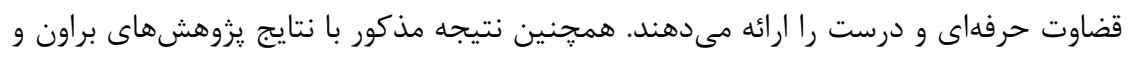

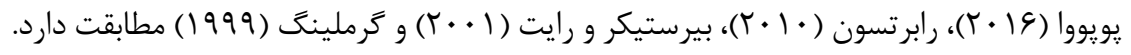

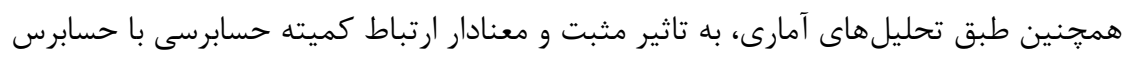

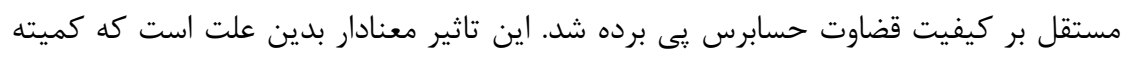

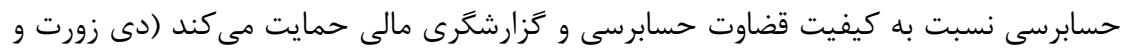

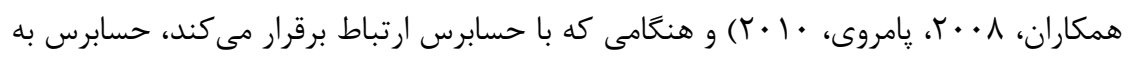

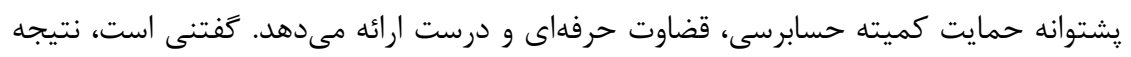

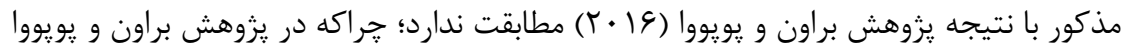

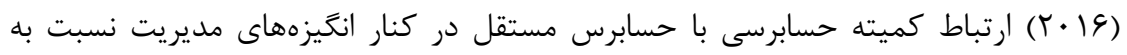

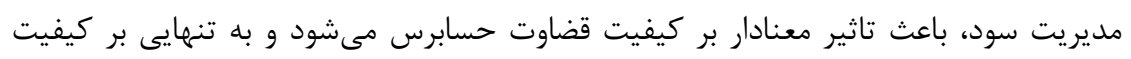

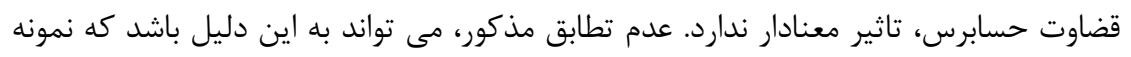

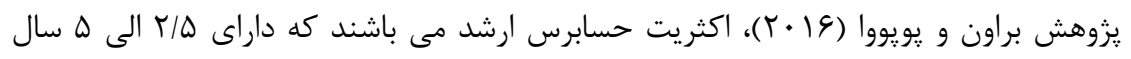

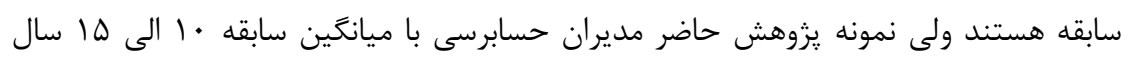


مىباشد كه قضاوت اين اشخاص نسبت به عمليات حسابرسى با يكديكر متفاوت مىباشد (كيبينز،

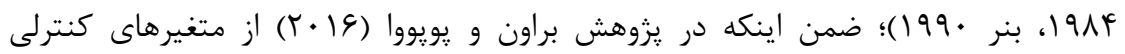

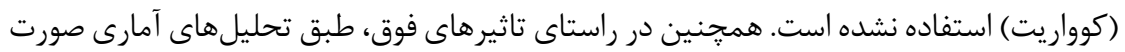

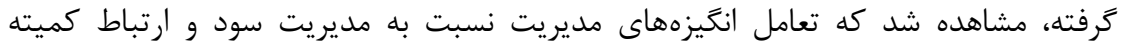

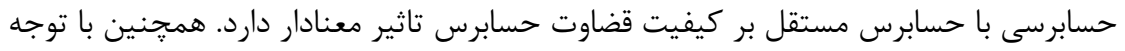

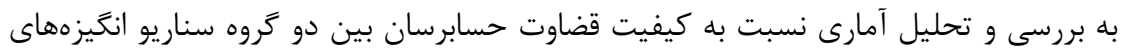

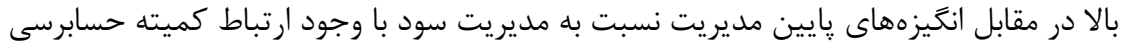

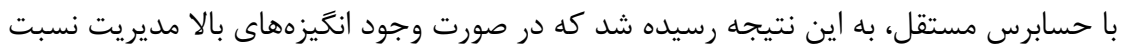

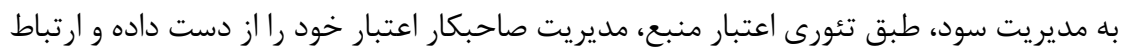

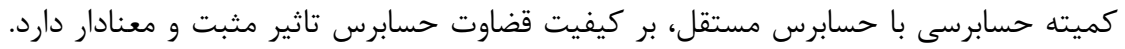

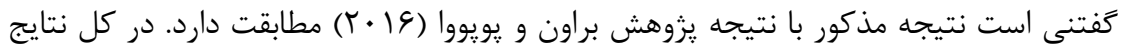

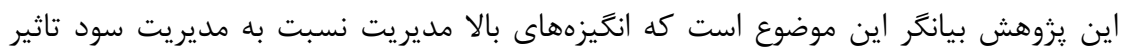
زيادى بر روى ارتباط كميته حسابرسى با حسابرس مستقل دارد. اين دستاوردها، اهميت ارتباط

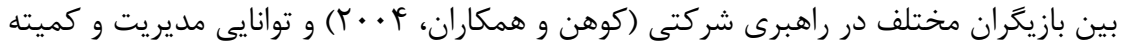

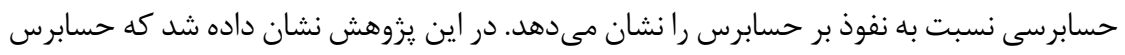

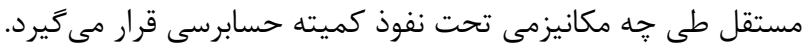

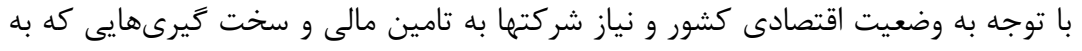

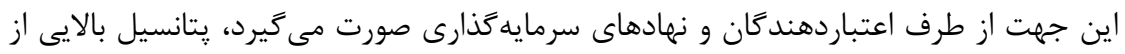

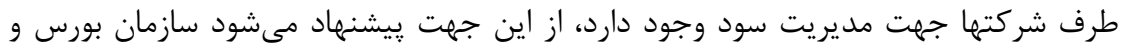

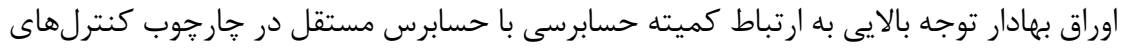

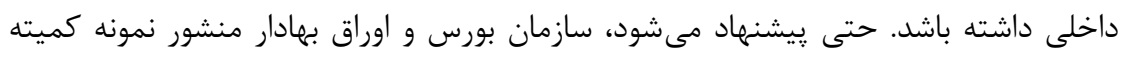
حسابرسى را بازنگرى نمايد و حداقل تعداد جلسات كميته حسابرسى با حسابرس مستقل رانس

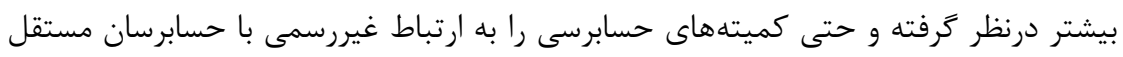

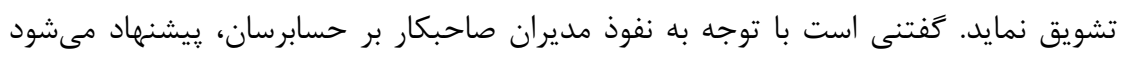

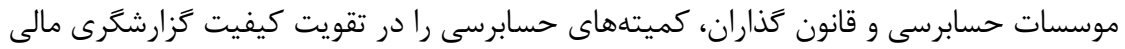
و عملكرد حسابرسى بيشتر مورد توجه قرار دهند.

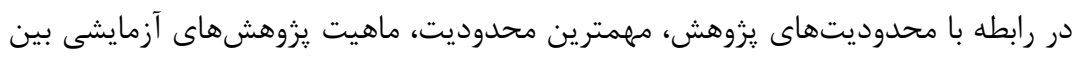

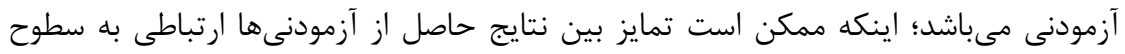

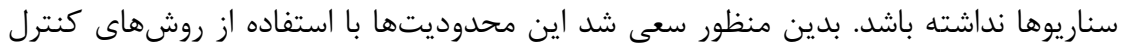

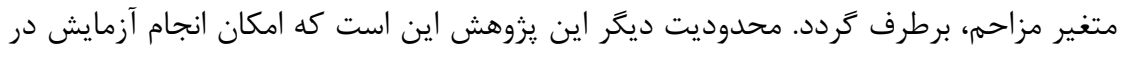


يك محيط با همه مديران حسابرسى وجود نداشت و در نتيجه موردهاى يزوهش براى مديران

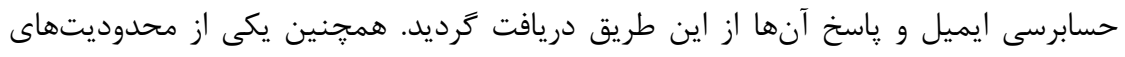

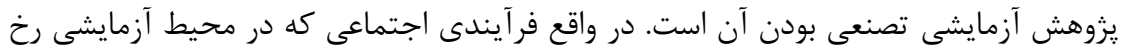

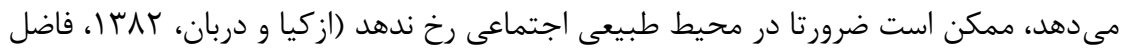

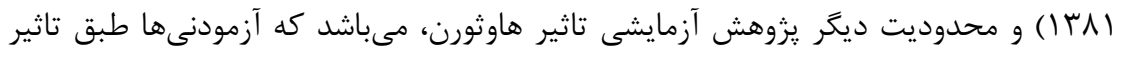

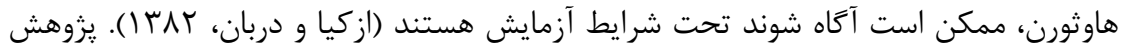

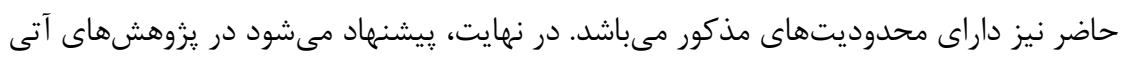

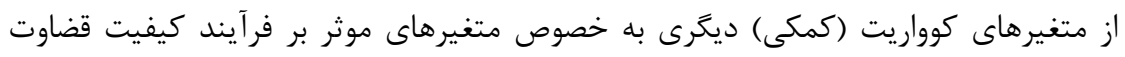

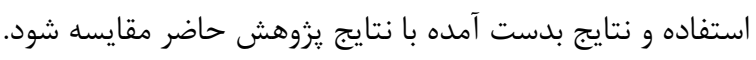

V- Vقدير، تشكر و ملاحظه هاى اخلاقى

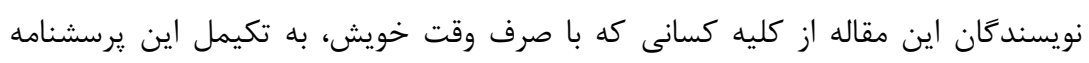

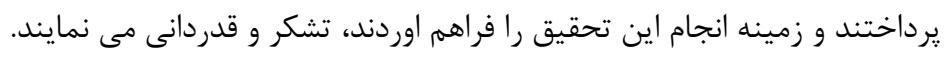

^- بيوست ها:

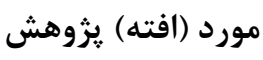

جهت انجام اين يزوهش براساس دستكارىهاى انكَيزههاى مديريت نسبت به به مديريت سود و

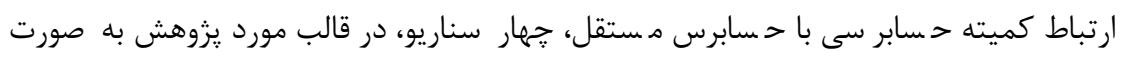

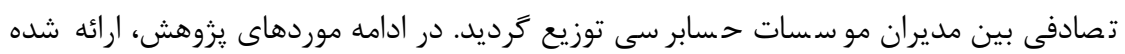
است:

\section{بسمه تعالى}

مدير حسابرسى محترم موسسه......

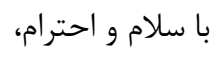

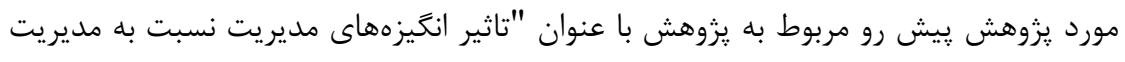

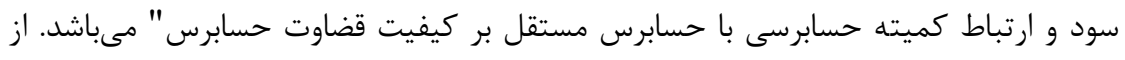

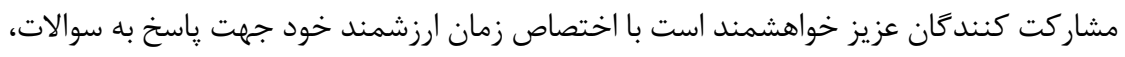

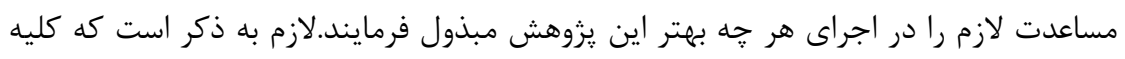

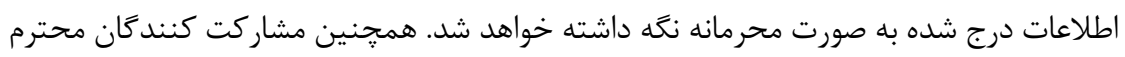

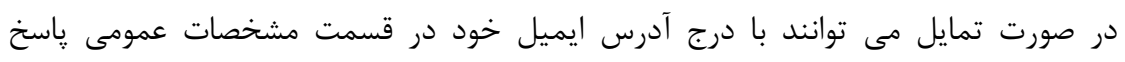
دهندكان، از نتايج اين يزوهش مطلع شورند 


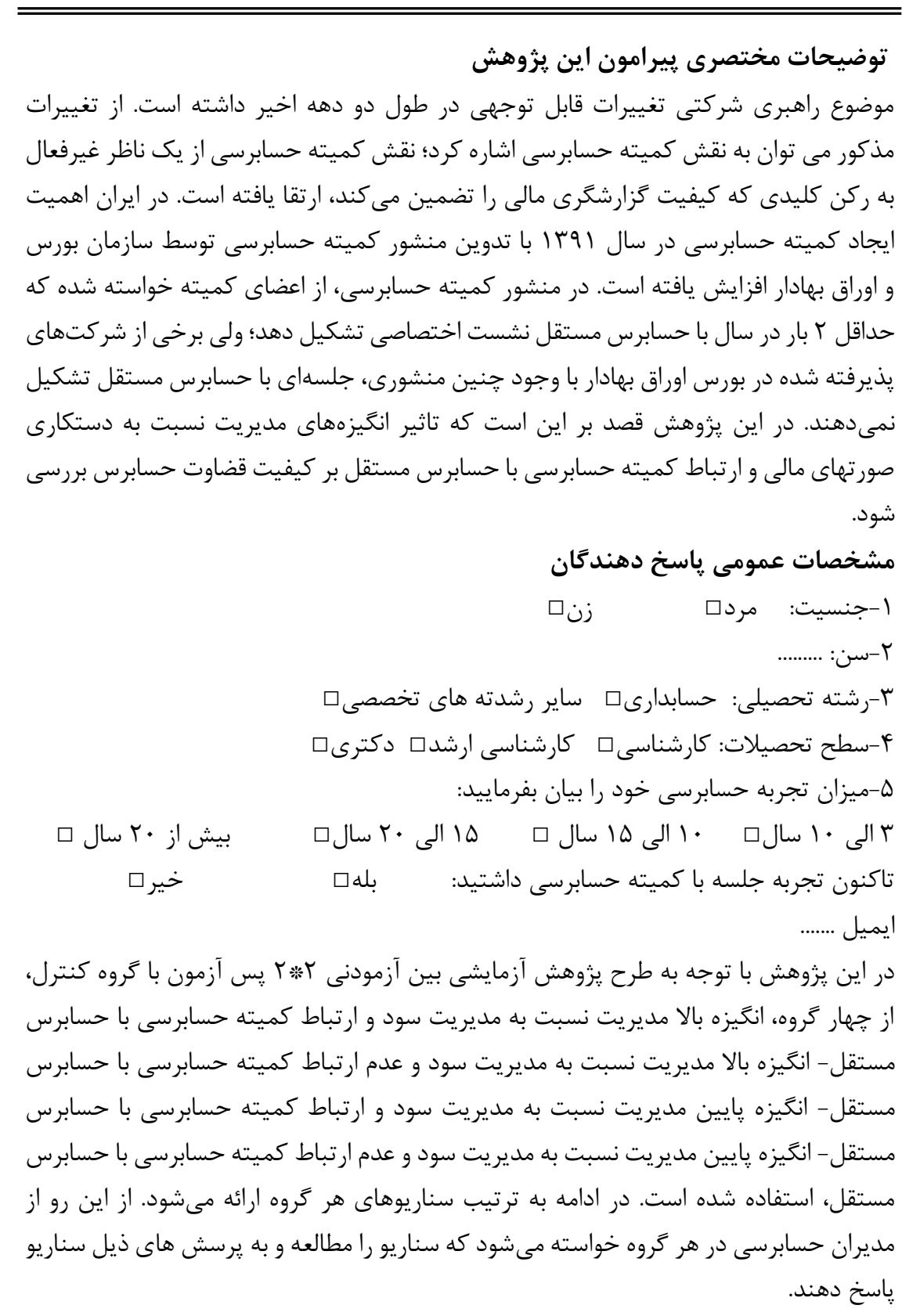

• سناريو مربوط به انكَيزه بالا مديريت نسبت به مديريت سود و ارتباط كميته حسابرسى با 
فرض كنيد حسابرسى صورتهاى مالى منتهى به 1T9V/IT/R9

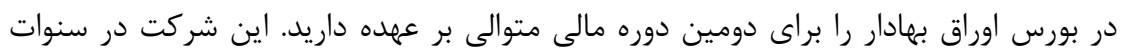

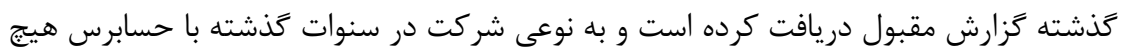

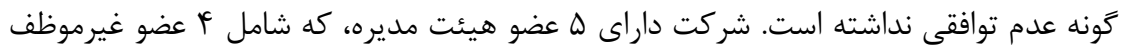

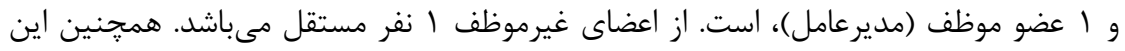

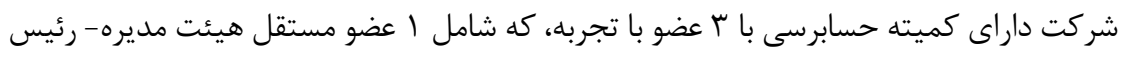

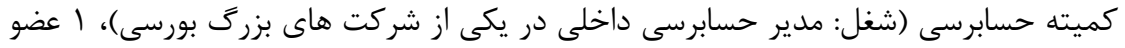

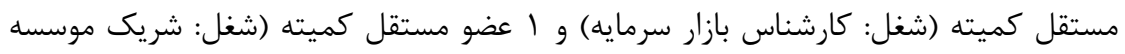

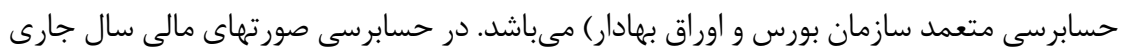

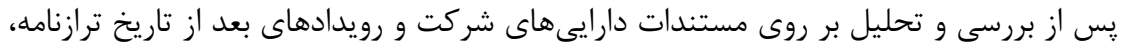

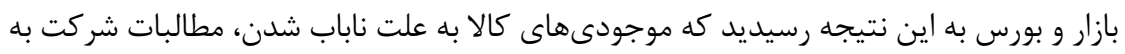

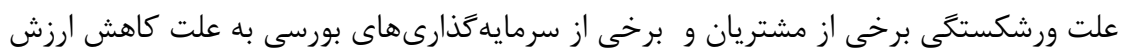

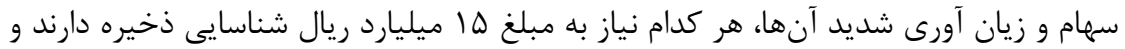

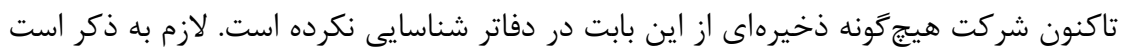

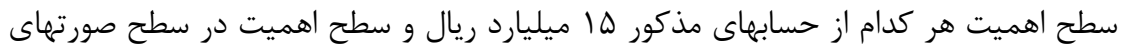
مالى (به صورت يك مجموعه) D\& ميليارد ريال مى مباشد.

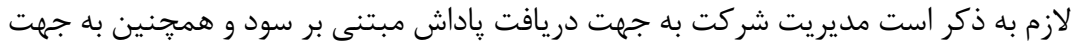

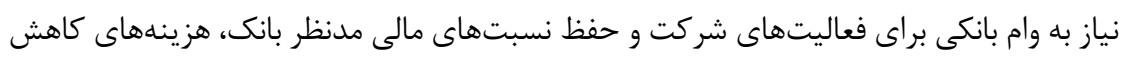

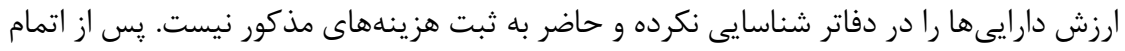

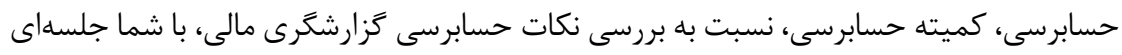

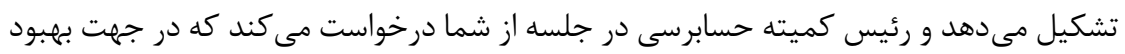

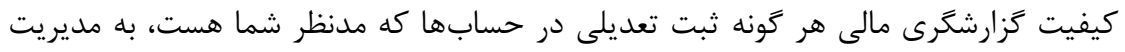
شركت بيشنهاد دهيد و در اين راستا، هيج كونه ثبتى از طرئه

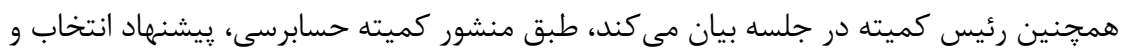

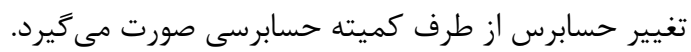

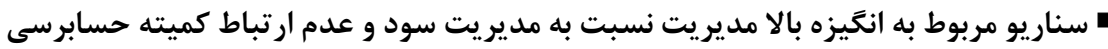
با حسابرس مستقل: فرض كنيد حسابرسى صورتهاى مالى منتهى به

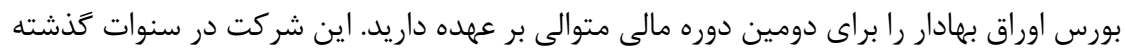

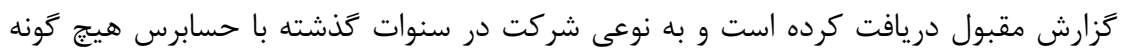


عدم توافقى نداشته است. شركت داراى ه عضو هيئت مديره، كه شامل f عضو غيرموظف و 1

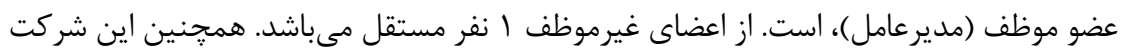

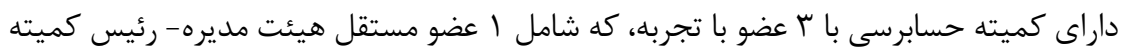
حسابرسى (شغل: مدير حسابرسى داخلى در يكى از شركت هاى بز بزر

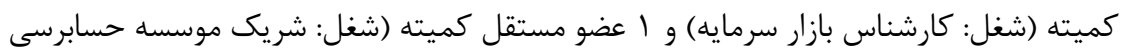

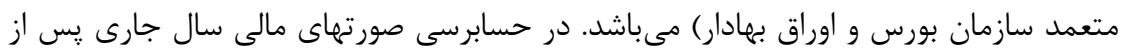
بررسى و تحليل بر روى مستندات دارايىهاى شركت و رويدادهاى بعد از تاريخ ترازنامه، بازار و و

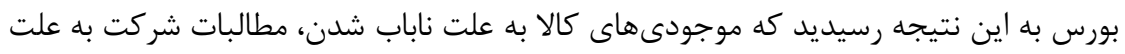

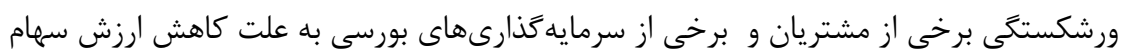

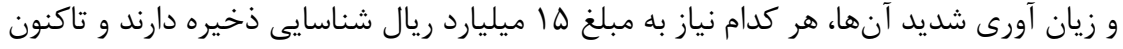

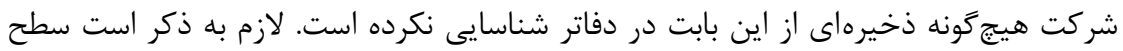

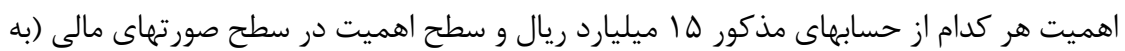
صورت يك مجموعه) D\& ميليارد ريال مى مباشد.

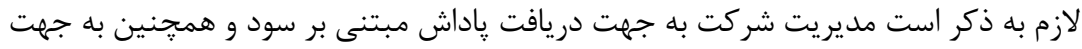

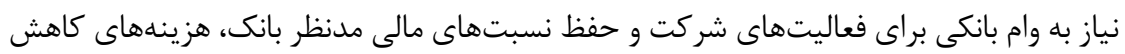

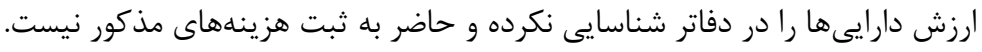

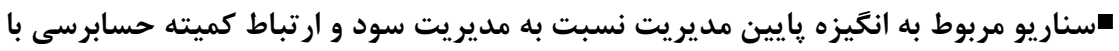

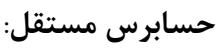
فرض كنيد حسابرسى صورتهاى مالى منتهى به

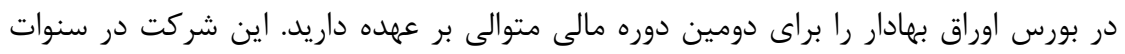
كذشته كزارش مقبول دريافت كرده است و به نوعى شركت در سنو

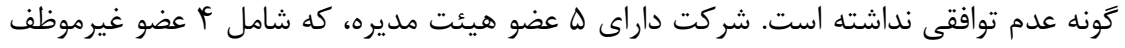

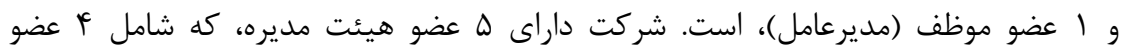

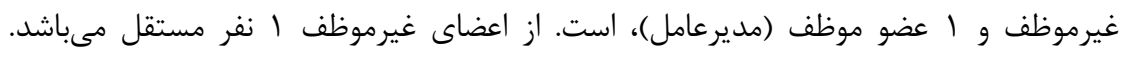

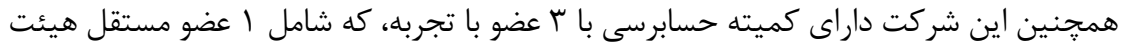

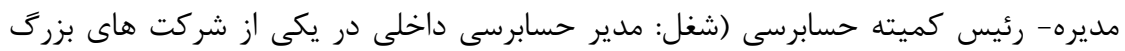

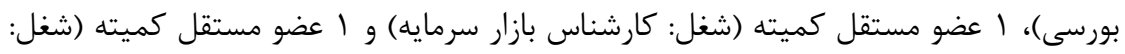

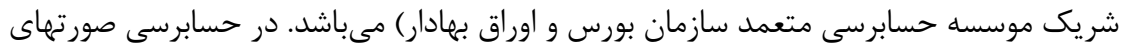

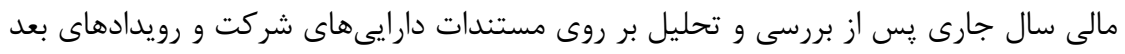

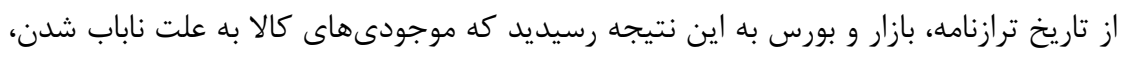


مطالبات شركت به علت ورشكستگى برخى از مشتريان و برخى از سرمايهَذارىهاى بورسى به

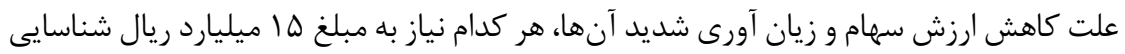

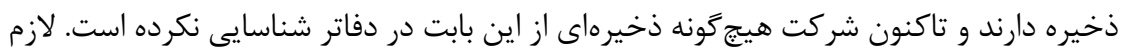

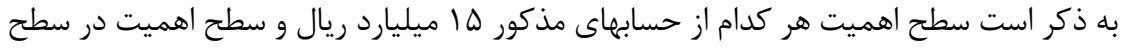

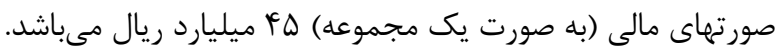

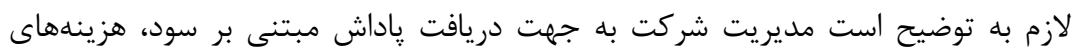

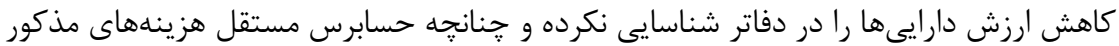

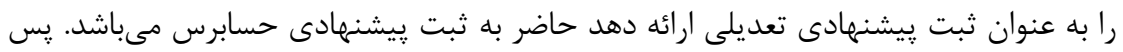

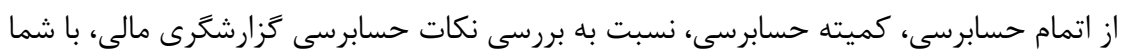
جلسهاى تشكيل مى دهد و رئيس كميته حسابرسى در جلسه از شما درخواست مى كند كه در در

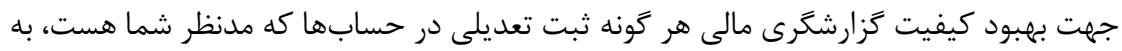

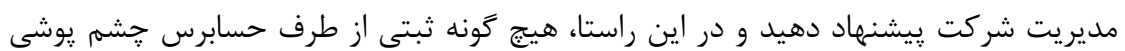
نشود. همجنين رئيس كميته در جلسه بيان مى كند، طبق منشور كميته حسابرسى، پِيشنهاد

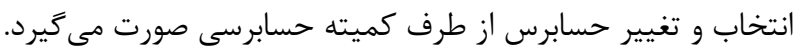

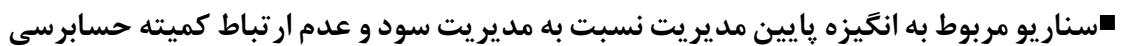

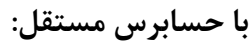

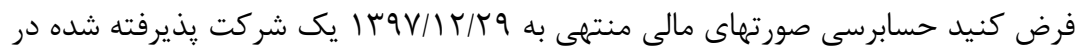

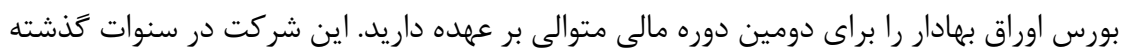

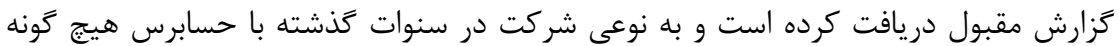

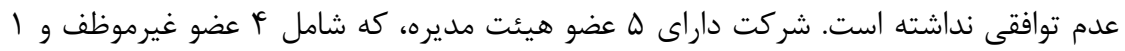

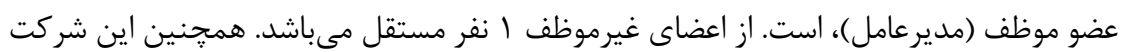
داراى كميته حسابرسى با ץ عضو با تجربه، كه شامل / عضو مستقل هيئت مديره- رئيس كميته

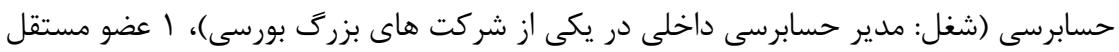

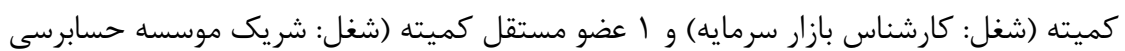

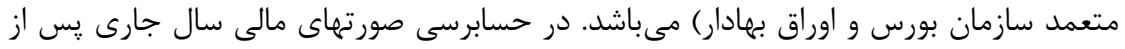

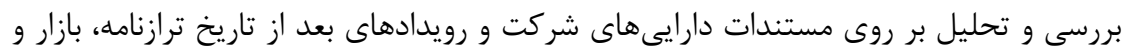

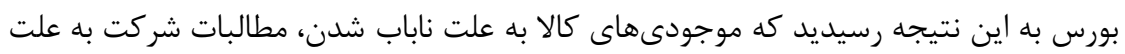

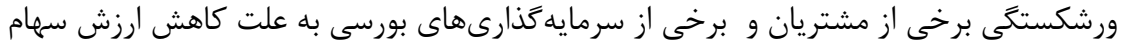

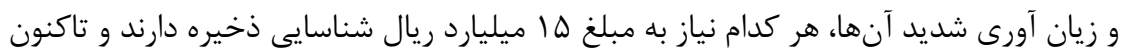

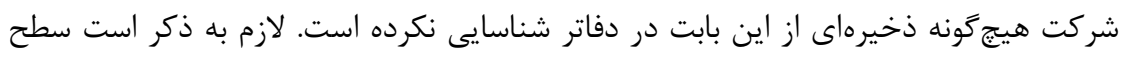


اهميت هر كدام از حسابهاى مذكور ها ميليارد ريال و سطح اهميت در سطح صورتهاى مالى (به مواله

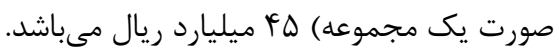

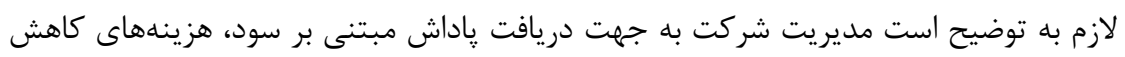

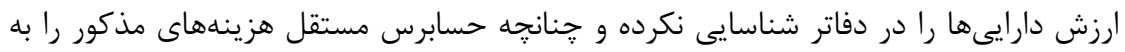

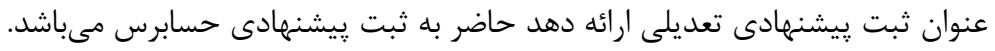

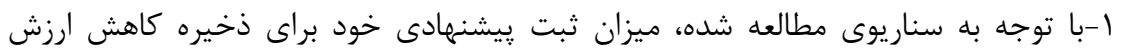

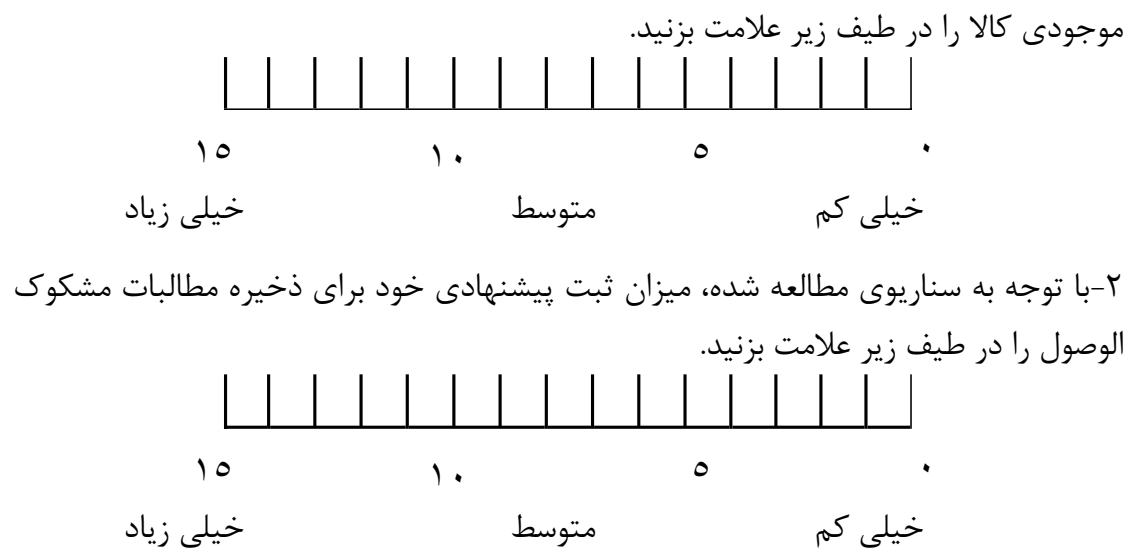

r-با توجه به سناريوى فوق ميزان ثبت ييشنهادى خود براى ذخيره كاهش ارزش سرمايه كذارىها

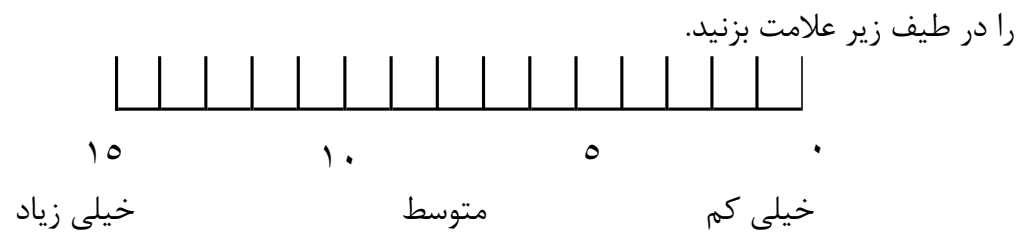

فهرست منابع

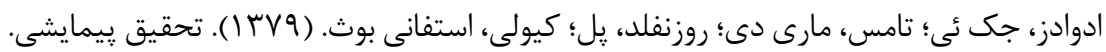

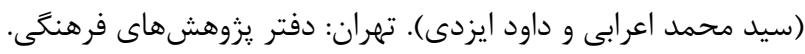

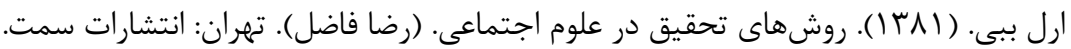

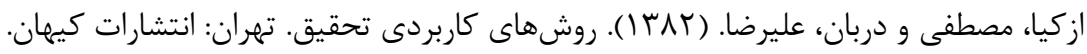

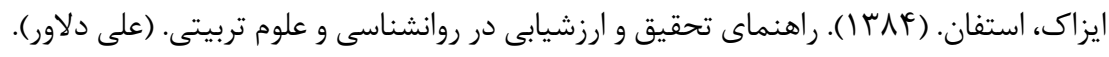

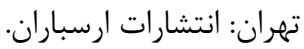


باديا، بهروز؛ يور حيدرى، اميد؛ خدامى يور، احمد. (1) (1))، اثر نغرشهاى حمايتى و آشنايى

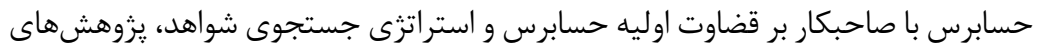

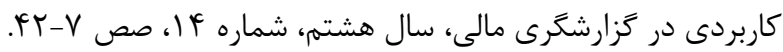

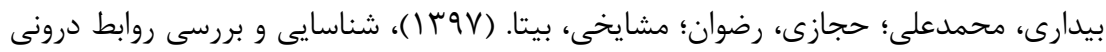

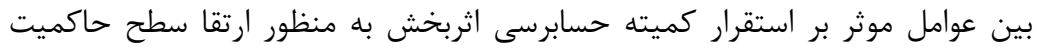

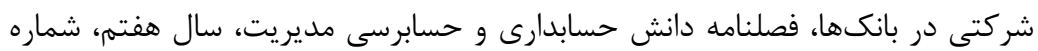

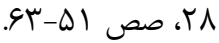

ياشا شريفى، حسن و شريفى، نسرين. (r/rا1). روشهاى تحقيق در علوم اجتماعى. تهران:

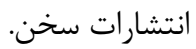

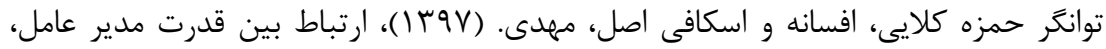

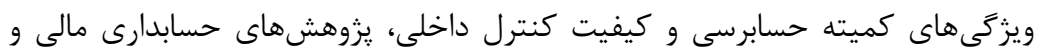

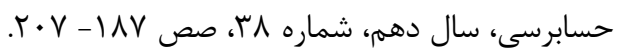

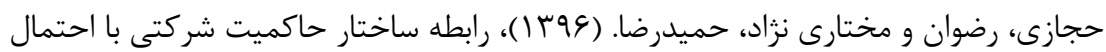

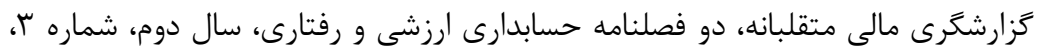

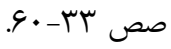

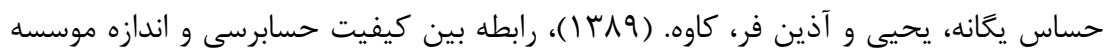

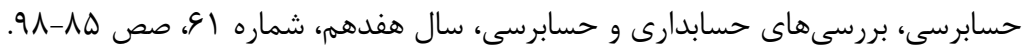

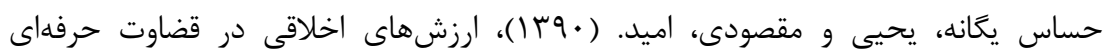

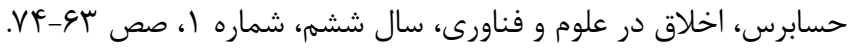

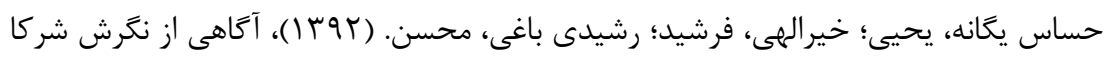

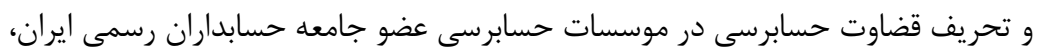

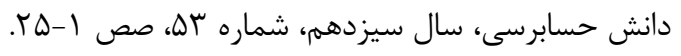

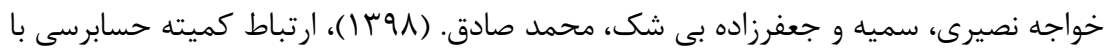

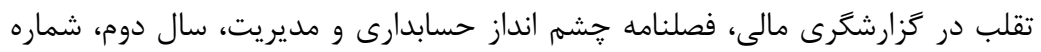

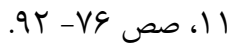

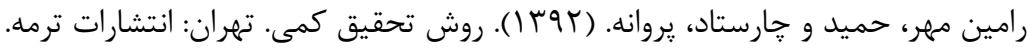

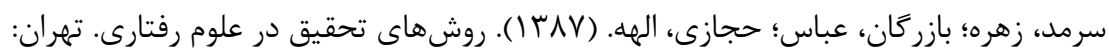

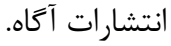

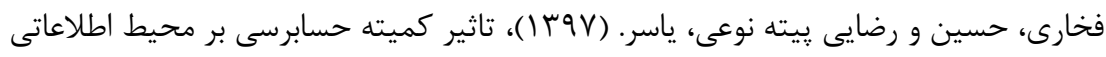

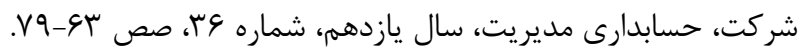




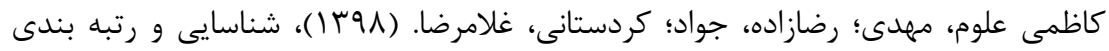

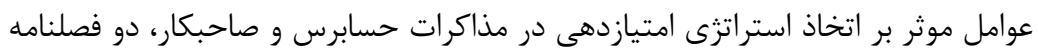

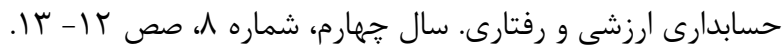

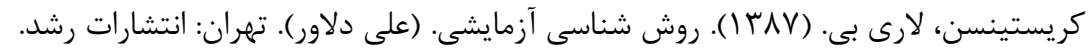

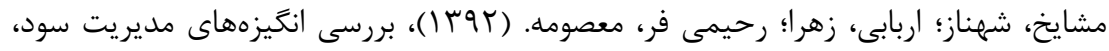

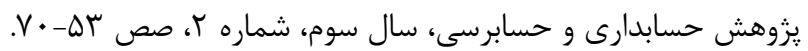

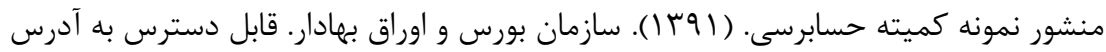

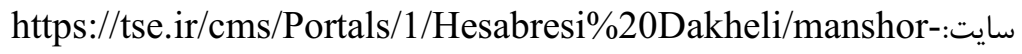

$$
\begin{aligned}
& \text {.komiteh-hesabresi-\%5B91-11-23\%5D45_1.pdf }
\end{aligned}
$$

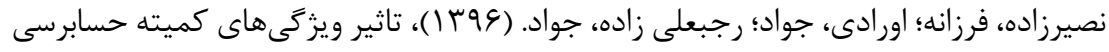

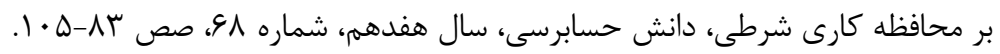

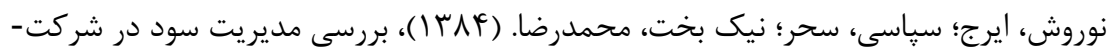

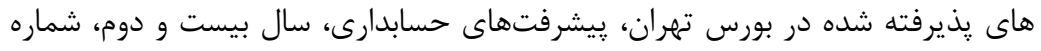

$$
\begin{aligned}
& \text { IVV-190 T) }
\end{aligned}
$$

Agyei- Mensah, B., and M. Yeboah. 2019. Effective Audit Committee, Audit Quality And Earnings Management: Evidence From The Ghana Stock Exchange. International Journal of Managerial And Financial Accounting 11 (2): 93-112.

Agyei-Mensah, B. 2018. The Effect Of Audit Committee Effectiveness And Audit Quality On Corporate Voluntary Disclosure Quality. African Journal Of Economic And Management Studies. Https://Doi.Org/10.1108/AJEMS-04-2018-0102.

Bagley, P. L. 2010. Negative Affect: A Consequence Of Multiple accountabilities in auditing. Auditing: A Journal of Practice \& Theory. 29 (2): 141-157.

Bamber, E. M., and V. M. Iyer. 2007. Auditors' identification with their clients and its effect on auditors' objectivity. Auditing: A Journal of Practice \& Theory. 26 (2): 1-24.

Beatty, R. P. 1989. Auditor Reputation and the Pricing Of Initial Public Offerings. The Accounting Review. 64 (4): 693-709.

Beaulieu, P. R. 2001. The effects of judgments of new clients' integrity upon risk judgments, audit evidence, and fees. Auditing: A Journal of Practice \& Theory. 20 (2): 85-99.

Behn, B., J.H. Choi, T. Kang. 2008. Audit quality and properties of analyst earnings forecasts. The Accounting Review. 83 (2): 327-359. 
دكتر نيك بخت و حسين يور، تاثير " انكَيزه هاى مديريت نسبت به مديريت سود" و ...

Bierstaker, J. L., and A. Wright. 2001. The effects of fee pressure and partner pressure on audit planning decisions. Advances in Accounting. 18: 2546.

Birnbaum, M. H., and S. E. Stegner. 1979. Source credibility in social judgment: Bias, expertise, and the judge's point of view. Journal of Personality and Social Psychology. 37 (1): 48-74.

Bonner S.E. 1990. Experience Effects In Auditing: The Role Of TaskSpecific Knowledge. The Accounting Review. 66: 72-92.

Bonner. S., 2007. judgment and decision making in accounting. university of southern California.

Brown, j. o., v.k. popova, 2016. the interplay of management incentives and audit committee communication on auditor judgment. behavioral research in accounting. 28 (1): 27-40.

Carcello, J. V., D. R. Hermanson, Z. X. Ye. 2011. Corporate Governance Research In Accounting And Auditing: Insights, Practice Implications, And Future Research Directions. Auditing: A Journal Of Practice \& Theory. 30 (3): 1-31.

Cohen, J., G. Krishnamoorthy, A. M. Wright. 2002. Corporate Governance And The Audit Process. Contemporary Accounting Research. 19 (4): 573-594.

Cohen, J., G. Krishnamoorthy. A. M. Wright. 2004. The corporate governance mosaic and financial reporting quality. Journal of Accounting Literature. 23 (1): 87-152.

Davidson, R. A. and D. Neu. 1993. A Rote on Association Between Audit Firm Size and Audit Quality. Contemporary Accounting Research. 9 (2): 479-488 .

DeAngelo, L., 1981. Auditor size and audit quality. Journal of Accounting and Economics. 3 (3): 183-199

DeZoort, F. T., D. R. Hermanson, R. W. Houston. 2008. Audit committee member support for proposed audit adjustments: Pre-SOX versus postSOX judgments. Auditing: A Journal of Practice \& Theory 27 (1): 85104.

Francis, J., \& J. Krishnan. 1999. Accounting accruals and auditor reporting conservatism. Contemporary Accounting Research. 16 (1): 135-165.

Gibbins., M. 1984. Proposition About The Psychology Of Professional Judgment In Public Accounting. Journal Of Accounting Research. 22 (1): 103-125.

Gibbins, M., and J. D. Newton. 1994. An empirical exploration of complex accountability in public accounting. Journal of Accounting Research. 32 (2): 165-186. 
Gramling., A. A. 1999. External auditors' reliance on work performed by internal auditors: The influence of fee pressure on this reliance decision. Auditing: A Journal of Practice \& Theory. 18: 117-146.

Herdman., R. K. 2002. Making audit committees more effective. Speech by SEC staff. Tulane Corporate Law Institute. New Orleans March Available at: http://www.sec.gov/news/speech/spch543.htm.

Kizirian., T., B. Mayhew, L. Sneathen, Jr. 2005. The impact of management integrity on audit planning and evidence. Auditing: A Journal of Practice \& Theory. 24 (2): 49-67.

O'Keefe., D. J. 2002. Persuasion: Theory and Research. Thousand Oaks. CA: Sage Publications.

Pomeroy., B. 2010. Audit committee member investigation of significant accounting decisions. Auditing: A Journal of Practice \& Theory. 29 (1): 173-205.

Pornpitakpan., C. 2004. The persuasiveness of source credibility: A critical review of five decades' evidence. Journal of Applied Social Psychology. 34 (2): 243-281.

Public Company Accounting Oversight Board (PCAOB). 2012. Communications with Audit Committees. Auditing Standard No. 16. Washington, DC: PCAOB.

Robertson, J. C. 2010. The effects of ingratiation and client incentive on auditor judgment. Behavioral Research in Accounting. 22 (2): 69-86.

Stefaniak., C. M., R. W. Houston, R. M. Cornell. 2012. The effects of employer and client identification on internal and external auditors' evaluations of internal control deficiencies. Auditing: A Journal of Practice \& Theory. 31 (1): 39-56.

Tajfel, H. 1974. Social identity and intergroup behavior. Social Science Information. 13(2): 65-93.

Wanda, A.Wallace. 1980. The Economic Role Of The Audit In Free And Regulated Markets. Graduate School Of Mangement. University Of Rochestor, NY. 